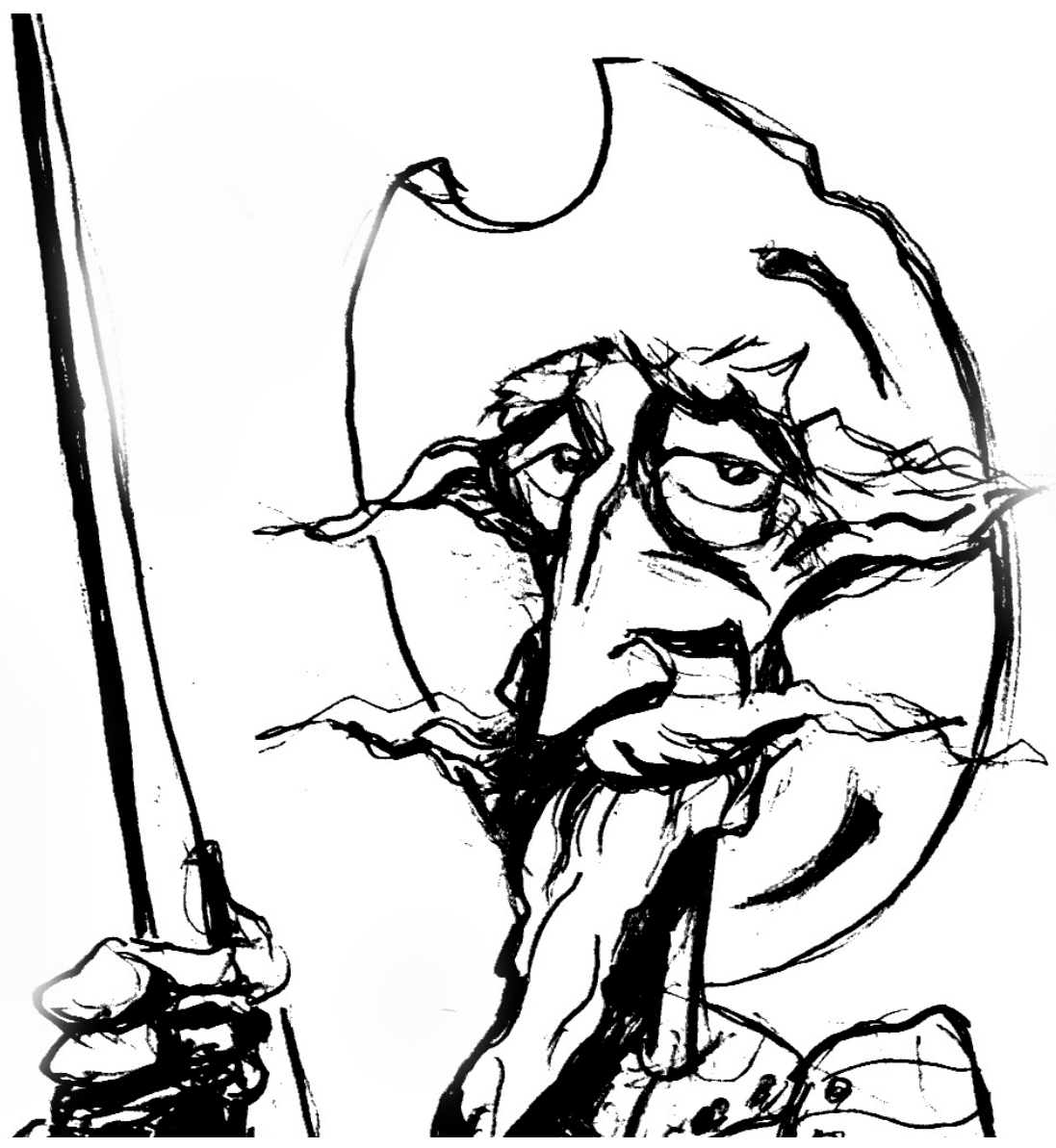

Libros de viajes, libros de trajes. Singularidad y tipificación del repertorio iconográfico americano en el siglo XVI

[Carolina Martínez] 



\section{Libros de viajes, libros de trajes. Singularidad y tipificación del repertorio iconográfico americano en el siglo XVI*}

\section{Travel Accounts and Costume Books. On the Singularity and Standardization of the American Iconographic Repertoire in the 16th Century}

CAROLINA MARTÍNEZ

\section{Resumen}

El artículo diferencia la producción de un repertorio iconográfico singular sobre América de su uso etno-iconográfico en los libros de trajes producidos en la segunda mitad del siglo XVI. Examina, en primer lugar, la forma en que la experiencia americana fue "traducida" en textos e imágenes inteligibles al lector europeo. Seguidamente, pone el foco en la segunda de las operaciones intelectuales mencionadas, pues analiza la presencia de imágenes sobre el Nuevo Mundo en nuevas cadenas de referencialidad y sentido. La incorporación de la iconografía americana en los libros de trajes revela sus potencialidades y limitaciones como dispositivos visuales y globales del saber tempranomoderno.

\section{Palabras clave}

Relatos de Viajes; Libros de Trajes; América; Iconografía; Modernidad Temprana.

\begin{abstract}
This article differentiates the production of a singular iconographic repertoire on America from its ethno-iconographic use in the costume books produced in the second half of the 16th century. Firstly, it examines the way in which the experience of travelers in America was "translated" into texts and images intelligible to the European reader. Then, it focuses on the second of the intellectual operations mentioned, as it analyzes the presence of images of New World in new chains of reference and meaning. The incorporation of American iconography in costume books reveals their potentiality and limitations as visual and global devices of earlymodern knowledge.
\end{abstract}

\section{Keywords}

Travel Accounts; Costume Books; America; Iconography; Early Modern Period.

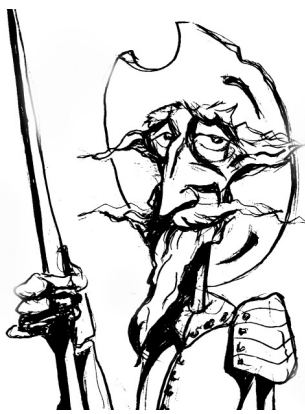

Recibido con pedido de publicación el 30 de marzo de 2020

Aceptado para su publicación el 3 de junio de 2020

Versión definitiva recibida el 2 de agosto de 2020

Carolina Martínez, Laboratorio de Investigación en Ciencias Humanas, Universidad Nacional de San Martín, Consejo Nacional de Investigaciones Científicas y Técnicas, San Martín, Argentina; e-mail: carolina.martinez@unsam.edu.ar

\footnotetext{
* Agradezco a los evaluadores anónimos de Revista Prohistoria

Esta obra se publica bajo licencia Creative Commons. Atribución-NoComercial-CompartirIgual $\underline{4.0 \text { Internacional }}$

Martínez, Carolina “Libros de viajes, libros de trajes. Singularidad y tipificación del repertorio iconográfico americano en el siglo XVI", Prohistoria, Año XXIII, núm. 34, dic. 2020, pp. 5-37.
} 
Desde los primeros viajes transoceánicos europeos a Lejano Oriente, los libros y mapas sobre el Nuevo Mundo ofrecieron al público lector europeo un repertorio de imágenes textuales y visuales que, en el transcurso del siglo XVI, se consolidó en una determinada forma de representar a América. La abundancia, la antropofagia, lo salvaje, la desnudez y la guerra devinieron, en el período señalado, tópicos a partir de los cuales la cuarta parte del mundo podía o debía ser reconocida. En términos alegóricos, estos se manifestaron en el tocado, la vestimenta, las armas o la fauna que a partir de 1570 acompañaron a la mujer-continente. A partir del frontispicio de Theatrum Orbis Terrarum (1570), realizado en base a las indicaciones de su autor, el geógrafo flamenco Abraham Ortelius, se impuso la representación alegórica de América como una mujer desnuda, robusta, con tocado de plumas y carcaj de flechas que, como preludio o consecuencia de un acto caníbal, sostenía la cabeza de un hombre en la mano.

Se trataba, tal vez, de la primera síntesis pictórica de los elementos que, desde los primeros relatos de exploración, habían sido asociados al Nuevo Mundo. A diferencia de las otras tres partes del orbe terrestre (Europa, Asia y África), Pars Quarta se distinguía por su naturaleza salvaje y su descubrimiento reciente. ${ }^{1}$ La contundencia de esta alegoría se manifestaría en sus innumerables apariciones -con leves modificaciones pero en lo fundamental invariable- en los siglos siguientes, toda vez que, en el caso de los frontispicios, la obra en cuestión refiriera a la totalidad del Orbis Terrarum o sus autores tuvieran por intención resaltar el tratamiento equitativo que su texto daba a las cuatro partes del mundo. En este sentido, era frecuente encontrar las alegorías de los cuatro continentes en los frontispicios de los libros de trajes, cuya ambición era, justamente, proporcionar una cobertura global de todas las vestimentas del mundo (Riello, 2019: 290).

La presentación de los trajes pertenecientes a sus cuatro partes, emulando la distribución espacial de los frontispicios de obras cartográficas, también podía realizarse en grabados individuales, como fue el caso de la plancha Costumes of the Nations of the World de Jost Amman (Figura 1), ${ }^{2}$ impresa

\footnotetext{
${ }^{1}$ Sobre la construcción de una alegoría de América en la Europa de los siglos XVI y XVII véase: Joris de Zavala (1983). La consagración de América como cuarta parte del mundo fue la consecuencia de un proceso histórico de alrededor de un siglo, en el que a los debates teóricos se sumaron las informaciones producidas en el marco de experiencias concretas de exploración. Las discusiones en torno al cambiante estatus geográfico del Nuevo Mundo han sido analizadas en profundidad por Carla Lois (2008).

2 En ella, Amman presenta las vestimentas típicas de Europa (que ocupa la totalidad de la mitad superior de la obra), África, América y Asia (que comparten la mitad restante). A su vez, las vestimentas incluidas dentro de cada sección corresponden a sus respectivas naciones: Brabante, Venecia, Nápoles, Inglaterra, Hungría, etc. son algunas de las palabras grabadas en la sección de Europa. Por su parte, "Barbaria", "Arabianer" y "Morenaus" aluden a los trajes de bárbaros, árabes y moros ilustrados para el caso de África. Mientras que los términos "tártaros",
} 
en Nuremberg en 1577 y actualmente conservada en el Museo Británico de Londres (Carvalho, 2019: 236). ${ }^{3}$ En otras ocasiones, sin embargo, la voluntad de representar las cuatro partes del mundo no trascendió los límites de la mera proposición: el Habitus variarum Orbis Gentium (1581 [1570]) de Abraham Bruyn, que no incluía vestimentas americanas, insinuaba lo contrario en su frontispicio (Figura 2).

\section{Figura 1}

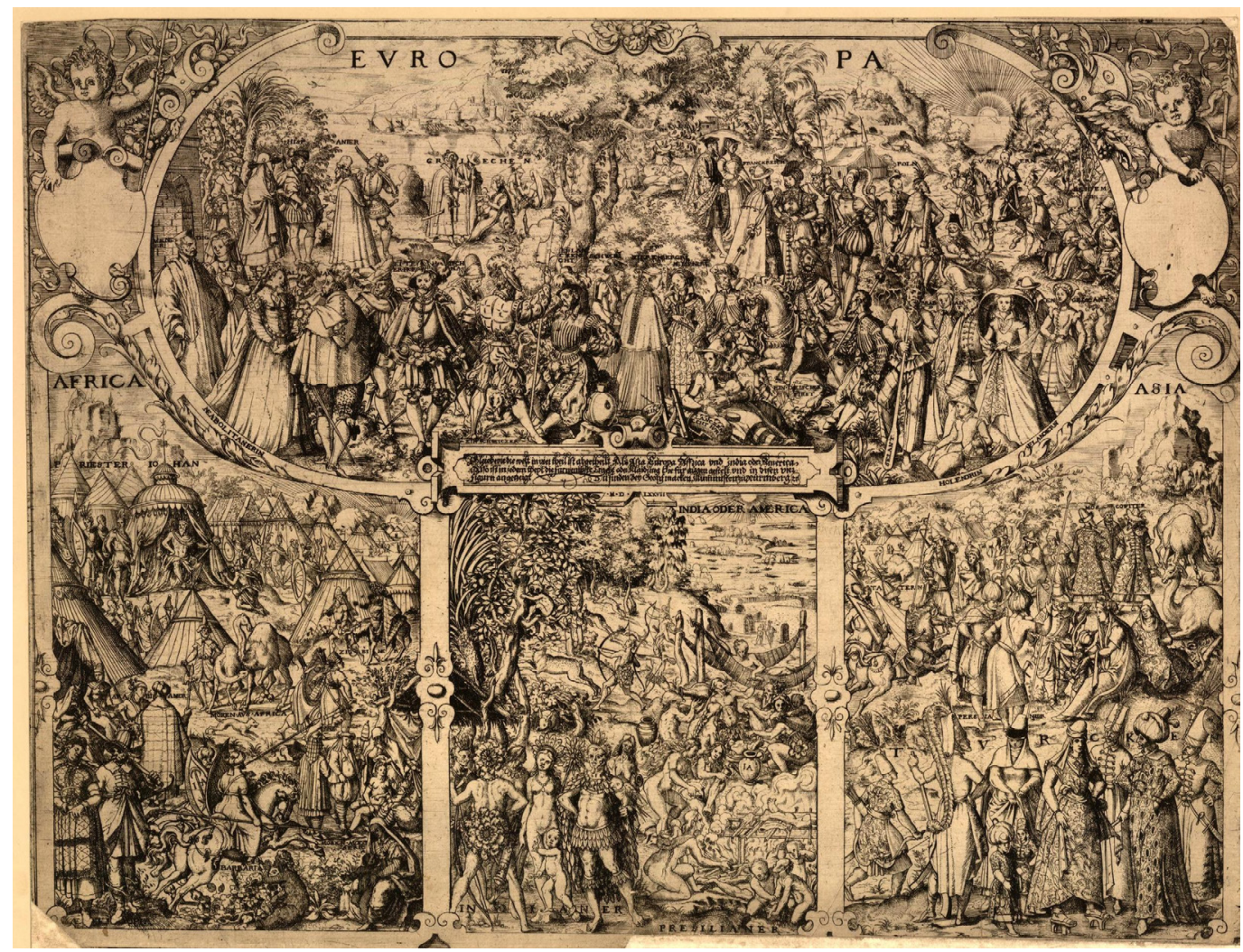

Jost Amman, Costumes of the Nations of the World, Nuremberg, 1577. Fuente: The Trustees of the British Museum.

\footnotetext{
"persas", "turcos" y "moscovitas" dan cuenta de los orígenes de las vestimentas correspondientes a la sección de Asia y un único término: "Indianer Presilianer" (sic.), en alusión a los indios de Brasil, tiene por intención referir a las vestimentas de América.

${ }^{3}$ Sobre la relación de los libros de trajes con el "impulso cartográfico" prevaleciente en este período véase Ilg (2004: 38).
} 


\section{Figura 2}

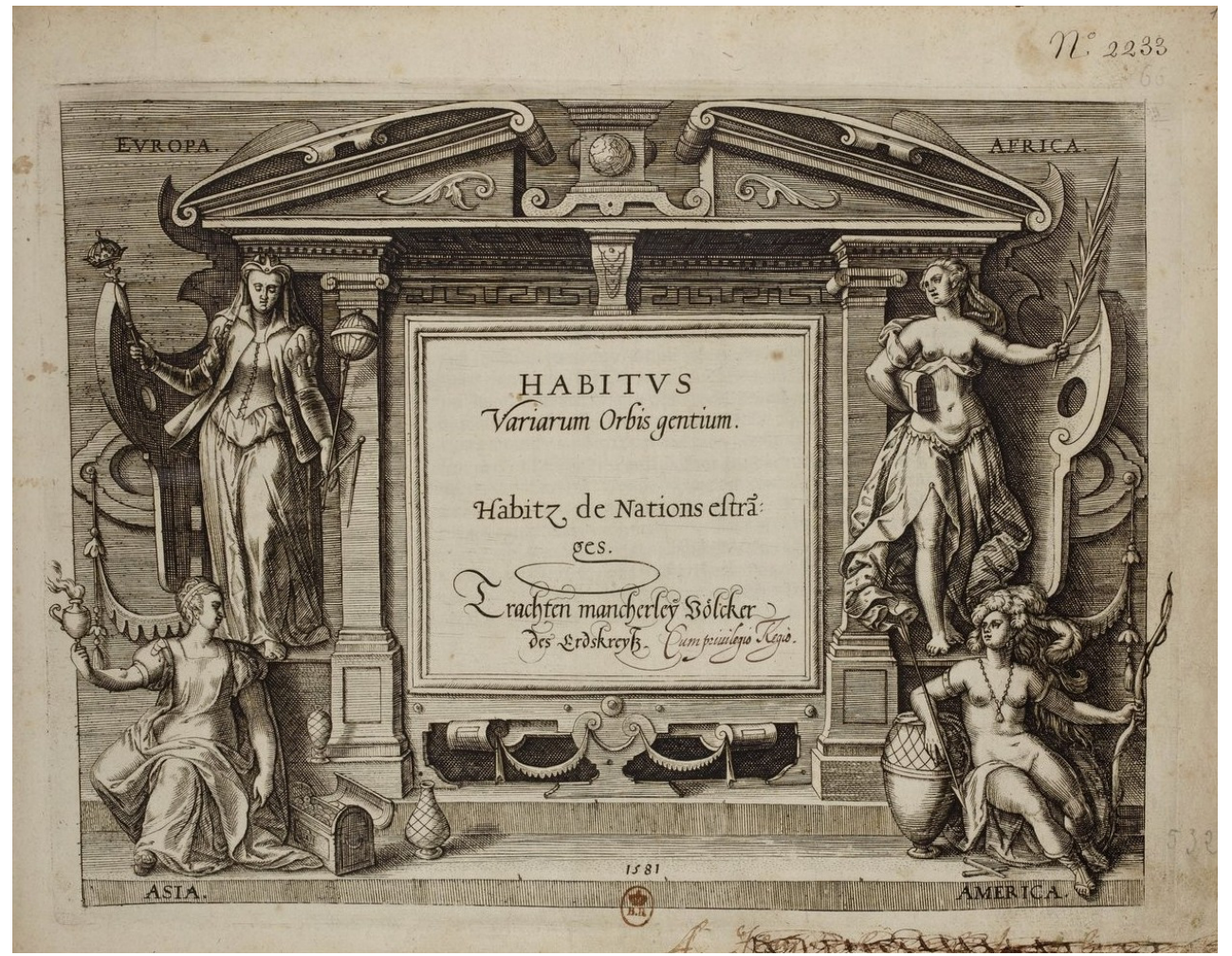

América yace a la derecha del frontispicio Abraham de Bruyn y Jean-Jacques Boissard, Habitus variarum Orbis Gentium. Habitz de nations estranges, Amberes, 1581 [1570]. Fuente: Biblioteca Nacional de Francia.

A comienzos del siglo XVII, en su Iconologia, overo, descrittione di diverse imagini cavate dall'antichita, $\mathcal{E}$ di propria inventione (1603), ${ }^{4}$ el artista perusino Cesare Ripa volvería a describir en detalle los componentes que, en su opinión, debía presentar toda alegoría de América. Su propuesta condensaba, una vez más, el conjunto de imágenes textuales y visuales sobre aquella región del mundo que, plasmado en diferentes soportes materiales, había inundado los mercados editoriales en las décadas precedentes. ${ }^{5}$

La construcción de una imagen inequívoca de Pars Quarta tal como se observa en los casos de Ortelius, Amman y Ripa se sustentó, básicamente, en el repertorio textual e iconográfico producido en torno a las primeras experiencias de exploración en el Nuevo Mundo. En principio, fue el testimonio de los viajeros al servicio de las distintas coronas europeas y el interés de sus editores

\footnotetext{
${ }^{4}$ [Iconología o nueva explicación de muchas imágenes, emblemas y otras figuras jeroglíficas de virtudes, vicios, artes, ciencias, causas naturales, humores diferentes, pasiones humanas, etc.] Tras una primera edición sin imágenes en 1593, la edición de 1603 contó con una serie grabados ilustrativos de los términos incluidos en el "diccionario de imágenes".

${ }^{5}$ La écfrasis de Ripa sobre los atributos de América ha sido analizada recientemente por Nicolás Kwiatkowski, quien también ha examinado la alegoría del continente en el frontispicio de Ortelius (Kwiatkowski, 2017: 72-3).
} 
los que dieron lugar a una serie de relatos e imágenes sobre el Nuevo Mundo. Algunas de estas últimas fueron concebidas por los propios viajeros en sus derroteros por territorios americanos y adaptadas, luego, por los grabadores al servicio de los principales impresores de Europa (Rubiés, 2008: 336-7). Otras, en cambio, originalmente producidas para ilustrar espacios y acontecimientos ajenos al Nuevo Mundo, fueron adaptadas para dar cuenta de los habitantes y las vivencias en las nuevas regiones descubiertas. ${ }^{6}$

Por su parte, fueron los cosmógrafos, editores y compiladores quienes incorporaron aquel repositorio textual e iconográfico dentro de géneros más vastos tales como la cosmografía, las historias universales, los atlas y los libros de trajes. Así como en el Theatrum Orbis Terrarum de Ortelius o en la Iconología de Ripa, en mayor o menor medida, todos ellos dieron cuenta de la relación dialógica establecida entre América y las otras tres partes del mundo. Producidas en contextos inicialmente vinculados a los viajes de exploración europeos, en el transcurso del siglo XVI las imágenes del Nuevo Mundo adquirieron una autonomía relativa que se manifestó en su inclusión y circulación en nuevos géneros textuales con finalidades diversas.

En función de lo antedicho, el presente artículo tiene por objetivo caracterizar y, en consecuencia, diferenciar la producción de un repertorio iconográfico singular sobre América en las primeras décadas del siglo XVI de su uso etno-iconográfico dentro de compendios más amplios hacia fines de esa centuria. Para ello, examina el género de los libros de trajes, cuyo surgimiento y creciente popularidad se constata en la segunda mitad del siglo XVI. Tanto su auge cuanto la variedad de ejemplares actualmente disponibles del género hacen de él un objeto de análisis privilegiado para explorar el proceso de síntesis e inclusión de "lo americano" dentro de un conjunto de saberes más vasto con destinos diversos. Con la finalidad de indagar en torno a los orígenes y disponibilidad de las imágenes sobre los habitantes del Nuevo Mundo presentes en los libros de trajes, la primera parte del artículo examina la forma en que la experiencia americana fue traducida textual y visualmente a partir de sus relatos inaugurales o de las llamadas "escrituras fundacionales".? Seguidamente, analiza el modo en que dicha información fue adaptada para integrar los libros de trajes. Estos últimos, al igual que otros géneros con repertorios iconográficos más amplios, priorizaron la exhibición de figuras y descripciones sobre los habitantes del orbe terrestre en su totalidad. La segunda parte del artículo también se detiene en las interpretaciones historiográficas existentes en torno de los alcances, usos y funciones de este género novedoso.

\footnotetext{
${ }^{6}$ Sobre el caso específico de las ilustraciones que acompañaron las primeras dos ediciones de los viajes de Hans Staden véase: Voigt y Brancaforte (2014). Los préstamos y adaptaciones realizados por la familia de editores de Teodoro De Bry han sido examinados por Michiel van Groesen (2012).

${ }^{7}$ La noción ha sido trabajada en profundidad por María Jesús Benites (2014).
} 
Por último, a través del análisis del repertorio iconográfico americano presente en los libros de trajes, el artículo en su totalidad busca reflexionar en torno a las operaciones textuales e intelectuales desplegadas por humanistas, editores e impresores en la construcción de una imagen renovada del orbe terrestre. Así como sucedió con otros géneros creados en el período de auge de la expansión transoceánica europea, se propone que el libro de trajes funcionó como un dispositivo visual eficaz para integrar las novedades de la expansión dentro de secuencias de sentido más amplias y estables. Tal como lo evidencian los textos del género, la selección de imágenes sobre el Nuevo Mundo realizada por sus autores y editores da cuenta del proceso de resignificación atravesado por el repertorio iconográfico americano desde sus contextos originales de producción hasta su inclusión, junto a grabados de otras regiones y períodos, en el "teatro del mundo". 8

\section{Imaginando América: la producción de un repertorio iconográfico sobre los habitantes del Nuevo Mundo}

Una rápida mirada al mundo del impreso en la Europa del siglo XVI, permite aseverar que tanto los relatos producidos en el marco de experiencias concretas de exploración al Nuevo Mundo cuanto la labor interpretativa de humanistas, grabadores y editores dieron origen a una serie de imágenes y tópicos inequívocamente vinculados a América. ${ }^{9}$ Al margen de su valor representacional, la singularidad de las imágenes disponibles en relatos y mapas supuso su identificación -más o menos directa- con un espacio geográfico determinado. En función de los objetivos del presente trabajo, merecen particular atención los grabados incorporados en las escrituras o relatos fundacionales que, editados en los principales centros intelectuales de Europa, proveyeron las descripciones inaugurales de los habitantes de Pars Quarta.

En principio, las cartas del navegante florentino Américo Vespucio, redactadas a partir de sus cuatro viajes (supuestos o no) a América, parecieran haber dotado a los habitantes del Nuevo Mundo de una identidad específica

\footnotetext{
${ }^{8}$ El orden dado a las imágenes en los libros de trajes recuerda por qué constituyeron verdaderos "teatros de naciones" (Blanc, 2006: 80). Para Alejandra Vega (2014), además de los libros de trajes, otros "teatros del mundo" fueron las historias y crónicas, los libros de emblemas, las iconografías y los libros de historia natural (párr. 13).

${ }_{9}^{9}$ No es la intención del presente artículo pasar revista a la totalidad del repertorio iconográfico producido en las primeras décadas de exploración y ocupación europea del territorio americano. De ser así, también deberían examinarse las representaciones cartográficas, pictóricas y escultóricas sobre la cuarta parte del mundo. Esta tarea -monumental, por ciertofue realizada algunas décadas atrás por Jean-Paul Duviols (1985), quien se dedicó exclusivamente al caso de la América hispana. Sobre la construcción de América como singularidad en la cartografía del siglo XVI, véase: Martínez (2019a: 40-46).
} 
con relativa celeridad. ${ }^{10}$ Más allá de que a principios del siglo XVI la expresión "nuevo mundo" incluyera todo aquel territorio recientemente hallado del que no se tuvieran noticias previas (Broc, 1986: 32), fue a partir de Mundus Novus (1503) y de la Lettera (1505) -la carta que Vespucio escribió a Piero Soderini-, que comenzó a delimitarse un espacio (al menos textual, pues los contornos del Nuevo Mundo no habían sido aún explorados) en donde "ubicar" paisajes, animales y sociedades de singulares características.

El éxito editorial de Vespucio fue refrendado por la Cosmographia Introductio de Martin Waldseemüller, quien en 1507 asignó al territorio recientemente descubierto el nombre del florentino. Las ediciones de los viajes de Vespucio contaron, en ocasiones, con imágenes para acompañar el texto. ${ }^{11}$ Se destacan, por ejemplo, los grabados de hombres y mujeres nativos incorporados a las ediciones de Mundus Novus realizadas en las ciudades de Núremberg y Augsburgo en $1505^{12}$ y a la edición de la Lettera realizada en Estrasburgo en 1509.13 En el caso particular de la edición de Mundus Novus realizada en Núremberg, esta incluyó un grabado en el que se retrataba a los hombres del Nuevo Mundo observando desde la costa una embarcación europea (Figura 3). Sus faldas y tocado de plumas se volverían una constante en las ilustraciones de relatos posteriores y, en consecuencia, una presencia ineludible en los libros de trajes que, publicados desde mediados del siglo XVI, quisieran dar cuanta de las vestimentas de las cuatro partes del mundo. ${ }^{14}$ Por su parte, la edición de Augsburgo introdujo un grabado de Johan Froschauer en el que, por primera

\footnotetext{
${ }^{10}$ Aunque, las cartas colombinas también alimentaron el imaginario sobre los habitantes de las tierras recientemente halladas, fue Vespucio quien reconoció en aquella masa continental un Nuevo Mundo.

${ }^{11}$ En el caso de Waldseemüller, el mapamundi incluido en su Cosmographiae Introductio ubicaba un papagayo -acaso una alusión a terra papagalli- en el límite entre lo que el cosmógrafo consideraba eran las posesiones portuguesas y castellanas en América. Su Carta Marina de 1516, en cambio, incluía dos escenas de antropofagia en el actual Brasil.

${ }^{12}$ Ese mismo año la obra también se imprimió con grabados en Estrasburgo. Debe aclararse que en el caso de la edición de Augsburgo, la referencia es al grabado y texto complementarios que se agregaron al relato.

${ }^{13}$ Según indica Surekha Davies, uno de los grabados de la edición de 1509 de la carta a Soderini ya había aparecido en la versión italiana de 1493 de la carta de Cristóbal Colón a Luis de Santángel (2016: 79). Por su parte, Lisa Voigt y Elio Brancaforte se han preguntado sobre la repetición de un mismo grabado en distintos relatos de viaje (2014: 367).

${ }^{14}$ Los múltiples usos y reapariciones de estas imágenes se constata en textos alejados en términos espaciales y temporales de estos relatos inaugurales. En 1600, por ejemplo, Barent Jansz Potgieter publicaría su Wijdtloopigh verhael van tgende de vijf schepen, un relato sobre la frustrada expedición a los mares del sur realizada por el viajero holandés Sebald de Weert, junto a imágenes de los habitantes hallados en la región magallánico-fueguina de similares características a los retratados en la edición de Mundus Novus realizada en Leipzig en 1505. La imagen, conservada actualmente en el Rijks Museum de Ámsterdam, puede consultarse en: https://www.rijksmuseum.nl/nl/zoeken/objecten?q=potgieter\&p=2\&ps=12\&st=Objects\&ii=10\#/R P-P-OB-80.285,22
} 
vez, se ilustraban escenas de antropofagia entre otras prácticas atribuidas a los habitantes costeros de América meridional (Chicangana-Bayona, 2013: 13-14). Al igual que en la edición de Núremberg, los personajes representados vestían plumas y portaban arcos y garrotes, además de realizar lo que (según el relato de Vespucio) eran sus actividades típicas. ${ }^{15}$ Contrariamente, en el caso de los grabados incorporados a la edición de la Lettera fechada en 1509, los nativos representados se encontraban totalmente desnudos, aspecto que sin dudas incidió en el escaso peso que estos grabados en particular tuvieron en el género de los libros de trajes.

\section{Figura 3}

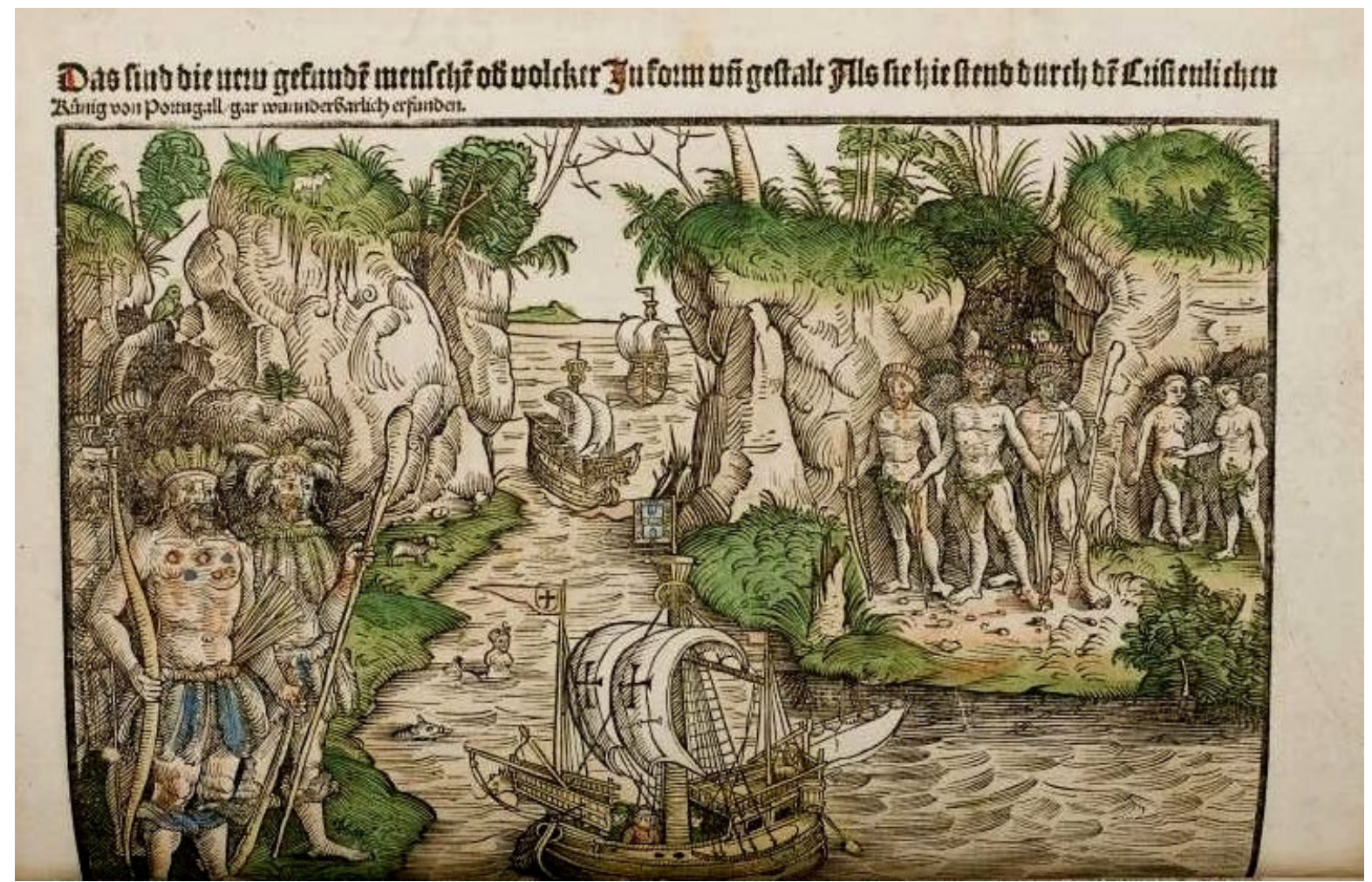

"Estas son las nuevas personas encontradas...", Américo Vespucio, Mundus Novus, Núremberg, 1505. Fuente: Wolfenbüttel, Herzog August Library. ${ }^{16}$

Se suma a las distintas ediciones de las cartas mencionadas, el relato del viaje que el soldado alemán Hans Staden realizara a las costas de Brasil entre 1549 y 1554. Publicada por Andreas Kolbe en la ciudad de Marburg en 1557, la obra de Staden llevó el sugerente título Verdadera historia y descripción de un país de salvajes desnudos, feroces y caníbales, situado en el Nuevo Mundo, América y contó con 54 grabados destinados a ilustrar las poblaciones tupíes con las que Staden

\footnotetext{
${ }^{15}$ Para una descripción pormenorizada de los grabados presentes en las ediciones mencionadas véase: Rubiés (2008).

${ }^{16}$ Si bien la imagen ha sido atribuida a la edición de Núremberg de 1505, algunos especialistas la han asociado a la edición de Leipzig de ese mismo año.
} 
convivió en los nueve meses que duró su cautiverio entre ellas. ${ }^{17}$ Además de narrar sus desventuras, en la segunda parte de la obra Staden describió algunos de los usos y costumbres de los nativos, que el editor complementó con la inclusión de grabados realizados bajo las indicaciones del viajero. ${ }^{18}$ Tal como ha señalado Hanno Ehrlicher, "al éxito de la primera edición contribuyeron de forma decisiva las numerosas ilustraciones, entre ellas las de las prácticas caníbales representadas con gran detalle y efectismo" (2014: 86). ${ }^{19}$ El impacto de tales imágenes se evidencia en las ediciones realizadas por Christopher Plantin en 1558, 1563 y 1627 y por Teodoro de Bry en 1593, que se basaron en los vívidos grabados de la editio princeps realizada por Kolbe en 1557. Por su proximidad al auge de los libros de trajes, interesa aquí el retrato de los tupíes presentado en la portada de la segunda parte de aquella primera edición (Figura 4), cuyo título fue: "Breve relato verídico sobre los modos y costumbres de los tupinambás, de quienes fui prisionero. Ellos viven en América. Sus tierras se encuentran 24 grados al sur de la línea equinoccial y limitan con el estuario de un río que se llama Río de Janeiro" (Staden, 2019 [1557]: 131). ${ }^{20}$ Ambos personajes portan la vestimenta e instrumentos propios del ceremonial antropofágico tupí, entre los que se destaca el Iwera Pemme o bastón ritual con el que los líderes asestaban el golpe letal a sus enemigos para luego comerlos. ${ }^{21}$ Tanto las faldas y tocados de plumas asociados a las descripciones de Vespucio cuanto la vestimenta y accesorios ceremoniales de los tupíes descriptos por Staden, se volverían insignias de Pars Quarta en los libros de trajes.

\footnotetext{
${ }^{17}$ La obra se publicó por primera vez en alemán con título Warhaftige Historia und beschreibung eyner landtschafft der Wilnen Nacketen Grimmigen Menschfresser Leuthen in der Newenwelt America. ${ }^{18}$ La tendencia a incluir imágenes por parte de los editores alemanes se refrendaría con la monumental colección Indias Occidentalis e Indias Orientalis (1590-1634) de la familia de grabadores de Teodoro De Bry. De hecho, De Bry retomaría el relato de Staden para incluirlo en su Americae tertia pars: memorabile provincix Brasilix historiam contines (dentro de la colección de relatos sobre América), editado en 1593 junto con los relatos de Jean de Léry y dos cartas del hugonote Nicolás Barré sobre su desafortunada experiencia en Brasil.

${ }^{19} \mathrm{Al}$ respecto, debe señalarse que en el período en el que se publicaron sus obras tanto Schmidl como Staden así como los editores de las primeras versiones de sus relatos y la familia De Bry adscribían al culto protestante.

${ }^{20}$ Esta como todas las traducciones del presente artículo, son nuestras.

${ }^{21}$ A la serie de imágenes vinculadas a Terra Brasilis se suman aquellas incluidas en la publicación de Singularidades de la Francia Antártica (1557), del cosmógrafo francés André Thevet, y en la Historia de un viaje hecho a la tierra de Brasil (1578), del pastor hugonote Jean de Léry. En ambos casos, aunque desde perspectivas religiosas contrapuestas, la descripción del intento de colonización francés en la Bahía de Guanabara fue acompañada de grabados en los que se daba cuenta de la exuberante fauna autóctona así como de las costumbres de las poblaciones tupí-guaraníes de la zona. Sobre la combinación de imagen y texto basados en la experiencia personal de Léry, véase Rubiés (2008: 329).
} 
Figura 4

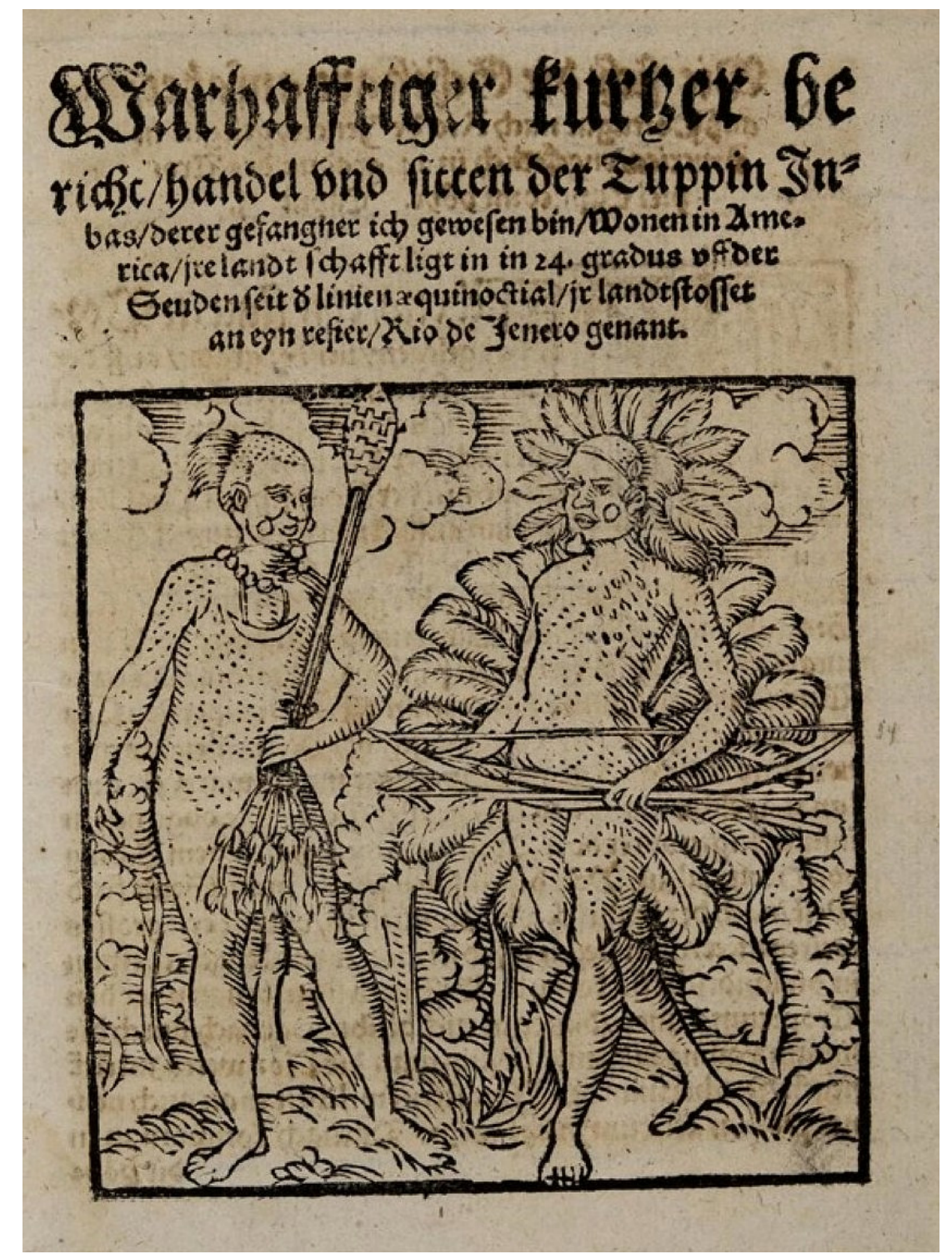

Hans Staden, Warhaftige Historia, Marburg, 1557. Portada de la segunda parte.

La primera edición del Viaje al Río de la Plata (1567) del lansquenete alemán Ulrico Schmidl, ${ }^{22}$ en cambio, no incluyó imágenes. Sí lo hicieron las versiones del texto publicadas hacia fines del siglo XVI por la familia de editores de Bry y el editor holandés Levinus Hulsius. ${ }^{23}$ Los cuatro grabados

${ }^{22}$ El relato fue publicado por el editor protestante Sigmund Feyerabend en la ciudad de Frankfurt en 1567 y se presentó como adenda al Weltbuch de Sebastian Franck de Word, complemento, a su vez de su Chronica, Zeitbuch und Geschichtsbibel, publicada en 1531 (El Jaber, 2013: 136). Schmidl estuvo en América entre 1535 y 1554 como parte de la expedición de Pedro de Mendoza. Para un estudio pormenorizado de la obra de Schmidl véase la reciente edición de su texto en español con prólogo de Loreley El Jaber (Schmidl, 2016 [1567]).

${ }^{23}$ En 1597, Teodoro de Bry editó la obra en alemán y hacia 1599 la tradujo al latín para incluirla en la séptima parte de su monumental colección Indiae Occidentalis o Americae. Ese mismo año el 
creados para la edición de de Bry fueron agregados por la familia de editores con la intención de denostar la presencia española en América en el marco de la posteriormente llamada "leyenda negra". Por su parte, la edición de Hulsius incluyó dieciséis figuras, destinadas a ilustrar algunos de los episodios narrados así como las distintas parcialidades encontradas por Schmidl durante su estancia de casi dos décadas en territorio americano. La aparición un tanto tardía de estas imágenes, sin embargo, se refleja en su escasa incidencia en los libros de trajes en relación con la influencia de las imágenes presentes en los relatos de Vespucio y Staden. ${ }^{24}$

Se observa entonces que no todos los relatos fundacionales estuvieron acompañados de grabados en sus primeras ediciones. Esto bien pudo haber acrecentado la influencia de las imágenes que sí fueron publicadas. En cuanto a las crónicas españolas, estas tampoco se destacaron por su profusión iconográfica. Tal como ha señalado Joan Pau Rubiés (2008) para el caso de Gonzalo Fernández de Oviedo,

"ni la edición de la primera parte de la Historia general y natural de las Indias, publicada en Sevilla en 1535, ni la reimpresión que siguió en 1547 tuvieron más que unos simples, por no decir toscos, dibujos de canoas, hamacas y chozas indígenas, varios animales como la iguana, y sobre todo árboles y otras plantas americanas, desde el maíz hasta la guanábana" (329).

Según explica el historiador catalán, en lo que refiere a los cronistas españoles: "era en el texto donde residía la autoridad subjetiva del historiador, único testimonio directo de la diferencia, y donde se creaba un contexto interpretativo para los grabados en madera..." (2008: 329).

Por su parte, las grandes compilaciones de viajes de la primera mitad del siglo XVI, tales como Paesi nuevamente ritrovati de Fracanzzo di Montalboddo de 1507 o el tercer volumen de las Navegaciones y viajes de Giovanni Battista Ramusio (publicado en 1556), tampoco incluyeron grabados de los episodios más relevantes narrados por los viajeros a tierras americanas ni de sus costumbres o vestimentas. En el caso de Ramusio, por ejemplo, primó la incorporación de imágenes sobre la flora, fauna y elementos propios de la vida material de las sociedades americanas. Escasas en número y acotadas, en general, a relatos puntuales, hasta la segunda mitad del siglo XVI las imágenes incluidas en las grandes compilaciones de viajes tuvieron menos relevancia que

relato también fue incorporado en la más económica compilación de viajes Sammlung von 26 Schiffahrten... de Levinus Hulisus (El Jaber, 2013: 136).

${ }^{24}$ Así como la primera edición del relato de Schmidl, tampoco contó con grabados la editio princeps de la Relación del primer viaje alrededor del mundo de Antonio Pigafetta, realizada en París en 1526 y en la cual el vicentino describía el primer viaje europeo alrededor del mundo (15191522). 
los textos en sí mismos. En efecto, el creciente peso de los grabados en obras de este tipo recién se evidencia a fines del siglo XVI, como resultado del impulso editorial de las ciudades holandesas y alemanas ${ }^{25} \mathrm{y}$, en consecuencia, no se condice con el período de auge de los libros de trajes. ${ }^{26}$

Resta señalar que, al margen del mundo del impreso, también se produjeron imágenes manuscritas cuya circulación en los medios cortesanos pudo haber incidido igualmente en la producción de imágenes representativas de América en los libros de trajes. Tal como ha indicado Larissa Carvalho, entre 1529 y 1532, durante una estancia en la corte de Carlos V, entre otros personajes que la frecuentaban, el artista alemán Christoph Weiditz retrató a un grupo de juglares mexicanos "ofrecidos" al rey por Hernán Cortés. La compilación de figuras de carácter manuscrito hecha por Weiditz, que también incluía vestimentas ibéricas, fue conocida como Trachtenbuch des Christoph Weiditz (Carvalho, 2020: 194) ${ }^{27}$ y constituyó la base de obras impresas posteriores (Blanc, 2006: 84)

¿Qué nos dice esto acerca de la producción de un repertorio iconográfico sobre los habitantes del Nuevo Mundo y su disponibilidad en un mercado editorial de objetivos más amplios? A partir de los casos hasta aquí analizados, es posible afirmar que la experiencia del viaje y exploración del territorio americano se tradujo en un conjunto de imágenes visuales -grabados principalmente, aunque también circularon imágenes manuscritas- cuya aparición se constata, primeramente, en algunos de los relatos fundacionales de la América colonial y, desde mediados del siglo XVI, en la publicación de relatos excéntricos a los núcleos principales de conquista y ocupación españoles del espacio americano, como fueron las áreas México y Perú. ${ }^{28}$ Ciertamente, no se ha tratado aquí de proporcionar una visión de conjunto de todas las imágenes sobre el Nuevo Mundo que pudieron haberse producido en el transcurso del siglo XVI. Antes bien, el análisis de los relatos producidos al calor de la experiencia en América ha permitido observar cómo en el caso de que contaran con imágenes que los acompañaran, estas se volvieron representativas del territorio y de sus habitantes, más allá de sus semblanzas o no. Su valor icónico se confirmaría con la aparición de géneros alejados del

\footnotetext{
${ }^{25}$ Las ediciones de Indias Occidentalis (Americae) e Indias Orientalis, producidas por la familia De Bry entre 1590 y 1634 y el Sammlung von 26 Schiffahrten... (1598-1660) de Levius Hulsius fueron los dos casos más relevantes.

${ }^{26}$ Un caso excepcional es la influencia de los grabados realizados por la familia De Bry (1590) en la segunda edición del libro de trajes de Cesare Vecellio (1598), que será analizado hacia el final del próximo apartado.

${ }_{27}$ Carvalho vincula la obra de Weiditz con la de Enea Vico, quien también visitó la corte de Carlos V y pudo haberse familiarizado con los dibujos del alemán (Carvalho, 2020: 195).

${ }^{28}$ La aparición de personajes mexicanos en los libros de trajes impresos bien pudo deberse a la influencia de las figuras manuscritas hechas por Weiditz y su circulación en determinados medios artísticos y cortesanos.
} 
proceso de expansión transoceánico europeo (o no dedicados a él exclusivamente) que, así como el libro de trajes, incluyeron las imágenes del Nuevo Mundo dentro de repertorios iconográficos más vastos.

\section{La tipificación de América en los libros de trajes, o su inclusión en el "teatro del mundo"}

Entre la segunda mitad y fines del siglo XVI, el libro de trajes resultó una novedad visual y textual en una Europa ávida de géneros que pudieran ordenar e incorporar los saberes de un mundo en expansión (Jones, 2006: 92). En principio, uno de los mayores desafíos presentados por la exploración transoceánica europea iniciada a fines del siglo XV fue la incorporación de nuevos conocimientos -por momentos contradictorios- al legado de la antigüedad clásica y la tradición bíblica. Por sus propias lógicas de producción y sentido, el libro de trajes, tanto como el atlas, el renovado género de la cosmografía $^{29}$ o las historias universales, resultaron dispositivos visualmente adecuados para dar cuenta en términos etnográficos, históricos y cartográficos de la totalidad del "teatro del mundo".

En lo que refiere específicamente al libro de trajes, entre 1562 y 1601, en las ciudades de París, Padua, Venecia, Frankfurt, Amberes y Ámsterdam, se publicaron en diversas lenguas cerca de quince obras de similares características (Jones, 2006: 92; Mentges, 2007: párr. 3). En 1562, François Desprez inauguró el género con la publicación de Recueil de la diversité des habits, qui sont de présent en usage, tant es pays d'Europe, Asie, Affrique $\mathcal{E}$ isles sauvages, le tout fait après le naturel, realizada en París por el editor protestante Richard Breton. Le siguieron las ediciones de Ferdinando Bertelli (Omnium Fere Gentium) y Nicolay D'Arfeuille (Les quatres premiers libvres des navigations et pérégrinations Orientales), realizadas en Venecia y Lyon un año después. En 1570 Abraham Bruyn publicó el ya mencionado Habitus Variarum Orbis Gentium ${ }^{30}$ y, en la ciudad de Núremberg, hacia 1577 Jost Amman hizo lo propio con Habitus praecipuorum populorum. Por su parte, Jean-Jacques Boissard editó su propio Habitus Variarum Orbis Gentium en Malina en 1581 y, posteriormente, una segunda obra, esta vez en francés, titulada Recueil de costumes étrangers. Jost y Bertelli volverían a publicar obras de similares características en 1586 y 1589 respectivamente, ${ }^{31}$ y Bartolommeo Grassi publicaría su Dei veri ritratti degli

\footnotetext{
${ }^{29}$ Sobre el auge del género cosmográfico se destaca el trabajo de Frank Lestringant (1991).

${ }^{30}$ Bruyn también publicó el Omnium pene Europae, Asiae, Aphricae atque Americae Gentium Habitus en Amberes en 1581. La obra fue titulada en alemán como Trachtenbuch der furnembsten Nationen und Volcker kleydungen beyde Manns und Weybs Personen in Europa, Asia, Africa und America.

${ }^{31}$ En el caso de Jost Amman se trató del Gynaeceum, sive theatrum mulierum, publicado en Frankfurt por Sigmund Feyerabendt hacia 1586. La obra de Bertelli se volvería a imprimir en 1569 y a reeditar en tres volúmenes bajo el título Diversarum nationum habitus en Padua en 1589, 1594 y 1596. Fue su hijo Pietro quien, bajo el título completo de Diversarum nationum habitus
} 
habiti di tutte le parte del mondo en Roma hacia 1585. El auge del libro de trajes se evidencia con la aparición de De gli Habiti antichi et moderni di Diverse Parti del Mondo de Cesare Vecellio, obra publicada en Venecia por Damian Zenaro en 1590 y reeditada con agregados sustanciales en 1598. ${ }^{32}$ Aunque en el transcurso del siglo XVII circularon nuevas versiones del género, su edad de oro pareciera haberse cerrado con las obras de Alexandro de Fabri (Diversarum Nationum Ornatus) y Jean de Glen (Des Habits, Moeurs, Cérémonies, Façons de Faire anciennes et modernes $d u$ Monde) publicadas en Padua y Lieja en 1593 y 1601 respectivamente (Olian, 2013: 36). ${ }^{33}$

La cantidad de obras editadas en el período señalado da cuenta, sin dudas, del interés que el género despertó entre sus lectores. En principio, es posible suponer que su creciente demanda radicó en que permitían "recorrer el mundo" sin la necesidad de desplazarse efectivamente. ${ }^{34}$ Esta aserción no deja de ser, sin embargo, una observación general, aplicable a todos los impresos en los que circulaban noticias de un mundo en expansión producto de los viajes de descubrimiento (Riello, 2019: 283). ¿En qué consistía la "novedad" de los libros de trajes, entonces? Según ha sugerido Odile Blanc, esta radicó en reunir en un único volumen imágenes de las vestimentas típicas de cada parte del mundo. La tarea, sostiene la autora, fue "iniciada por los impresores y grabadores, y no por los autores en el sentido en el que los entendemos hoy día..." (Blanc, 2006: 78). Más allá de la función que cupo a sus diferentes creadores, fue una característica del género presentar las vestimentas de todas las naciones del mundo a través de personajes masculinos y femeninos que, individualmente, realizaban alguna acción propia de la vida cotidiana. Por su parte, cada uno de los títulos y textos breves (si los había) que acompañaban las imágenes referidas, completaban la información visual provista.

En otras palabras, la novedad del género residió en la presentación de una ecúmene ampliada a través de la vestimenta "en el formato interrumpido de la hoja de papel" (Vega, 2014: párr. 15). Si el libro de trajes representaba en

centum et quattuor iconibus in aere incisis diligenter expressi, item ordines duo processionum, unus Summi Pontificis, alter Sereniss. Principis Venetiarum, opera Petri Bertellii, realizó la reedición de Omnium Frere Gentium (Ilg, 2004: 30).

32 En la opinión de Jo Ann Olian, De gli Habiti antichi et moderni di Diverse Parti del Mondo, de Cesare Vecellio, fue "la colección más completa de trajes de diversos países, y la primera en incluir vestimentas de períodos previos" (2013: 29). A los fines del presente artículo resulta de interés destacar que en su re-edición de 1598, la obra incluyó 87 grabados de trajes del Nuevo Mundo llegando a un total de 507 planchas.

33 A las obras ya citadas debe agregarse Omnium poene Gentium imagines, ubi oris totiusque corporis $\mathcal{E}$ vestium Habitus... exprimuntur, publicada por el editor Caspar Rutz en Colonia hacia 1577, y las reediciones de varias de los títulos mencionados.

34 En la opinión de Ann Rosalind Jones, los libros de trajes dieron al lector la posibilidad de viajar desde la comodidad del impreso, aspecto que según la investigadora explicaría la popularidad del género (2006: 94). 
una superficie plana la totalidad del espacio terrestre, era el traje el que actuaba como descriptor y/o decodificador de los habitantes del mundo. Más allá de los alcances y limitaciones de aquella aspiración ecuménica, el objetivo de los libros de trajes fue, según Alejandra Vega, dar cuenta "del conjunto del orbe a partir de la vestimenta de las diversas naciones que poblaban su geografía" (Vega, 2014). A su vez, el auge del género en la segunda mitad del siglo XVI respondió a la necesidad de crear un espacio de racionalización en el que pudiera gestarse la imagen de un mundo ampliado por la expansión transoceánica. Al igual que el atlas, que presentaba en un mismo formato cada una de las regiones en las que se dividía el orbe terrestre, ${ }^{35}$ el libro de trajes buscó clasificar la diversidad humana en torno a un aspecto común y a la vez diferenciable: su vestimenta (Jones, 2006: 93). Para ello, retomó la secuencia de las cosmografías universales, pues aspiró a "contener el mundo en un libro" al ofrecer al lector la posibilidad de observar, de una sola vez, la variedad de costumbres, pueblos, culturas y vestimentas que encerraba el mundo (Vega, 2014: párr. 12). La tipificación devino, en consecuencia, una condición del género.

Ahora bien, si para algunos investigadores el despliegue en una secuencia tipificada de figuras vestidas acorde a su procedencia hizo del libro de trajes una proto-etnología, para otros, la estandarización de los cuerpos y vestimentas en figuras desprovistas de sus contextos de acción redujo las cualidades cognoscitivas del género. Dentro del primer grupo, Ann Rosalind Jones ha resaltado el carácter etno-iconográfico de los libros de trajes (2006: 93), concepto que retoma del sociólogo francés Daniel Defert (1985). En la misma línea, Michelle Moseley-Christian ha considerado que tanto la cartografía temprano moderna cuanto los libros de trajes actuaron como "descifradores de sentido" de un mundo en gran parte desconocido por los lectores europeos (2013: 2).

Para Giorgio Riello, por el contrario, más allá de su naturaleza global, los libros de trajes no deberían ser interpretados como obras de carácter etnográfico necesariamente, pues su "carencia de contexto los convirtió en abstracciones más que en representaciones de personas" (2019: 292). Sobre el carácter de las ilustraciones contenidas en ellos, Riello ha hecho hincapié en su escaza variedad y en el hecho de que, además de estandarizar los cuerpos, las obras proveyeron poca información visual sobre los lugares referidos. A partir de estas observaciones, si bien reconoce su disposición en una secuencia determinada

\footnotetext{
35 Todos los mapas que integraban un atlas debían imprimirse en el mismo tamaño de página, elaborase en el mismo estilo, utilizar las mismas referencias, etc. En el caso del Theatrum Orbis Terrarum, por ejemplo, "ya no nos sorprende ver a Ortelius designar su obra mediante el nombre de Teatro. Pues es la palabra "teatro" la que resume, en cierto sentido, a finales del Renacimiento, la reflexión general que consiste en reunir de manera sintética un gran número de informaciones en un pequeño espacio para que sea fácilmente accesible a través de la mirada" (Besse, 2005: 119).
} 
por criterios lógicos y espaciales, el autor señala la falta de conectividad entre las distintas imágenes presentadas por este tipo de textos (2019: 286). Seguidamente, Riello los equipara con las historias del mundo producidas en el siglo XVI. Para ello, retoma las reflexiones de Sanjay Subrahmanyam, quien no solo destaca el carácter acumulativo de las "World Histories", sino el hecho de que, a diferencia de las historias universales, estas estuvieron "frecuentemente desordenadas y fueron ciertamente de naturaleza asimétrica" (2005: 36). Dentro de este segundo grupo debería agregarse por último la propuesta de Ulrike Ilg quien, al margen de lo anacrónico que pueda resultar el término, resalta el carácter enciclopedista de los libros de trajes (2004: 33).

Más allá de las reservas sobre la potencialidad etnográfica de los libros de trajes, lo cierto es que se tratase de etno-iconografías o de secuencias en el fondo desconectadas, por su propia definición las figuras incluidas en ellos pretendieron dar cuenta de las cuatro partes del mundo. En principio, ello implicó la inclusión de grabados con los trajes de Pars Quarta. El hecho de que tanto los frontispicios como los títulos anunciaran la representación de todas las vestimentas del orbe no garantizó, sin embargo, una cobertura simétrica o equilibrada de sus cuatro partes. ${ }^{36}$ Por el contrario, en los libros de trajes publicados entre la segunda mitad y fines del siglo XVI prevaleció la inclusión de figuras de Medio Oriente, ricas en detalles y en variaciones etarias y de género. Las vestimentas de los habitantes del Nuevo Mundo, en cambio, estuvieron representadas en cantidades bastante menores que el resto, contándose, en ocasiones, una única figura y, a veces, ninguna. Según las estimaciones de Nicole Pellegrin, "de un total de más de dos mil planchas en seis de los libros de trajes más importantes, no más de treinta están dedicados a América" (1987: 520-1). ${ }^{37}$

En la opinión de Alejandra Vega, su presencia cuantitativamente menor respondió a las "condiciones de circulación de las noticias americanas", que se tradujeron en la producción escasa de imágenes y su diseminación en ámbitos acotados (2014: párr. 5). ${ }^{38} \mathrm{El}$ análisis de los grabados sobre el Nuevo Mundo difundidos en los principales centros editoriales europeos confirma que hacia la segunda mitad del siglo XVI el repertorio de imágenes sobre América era relativamente escaso pero se complementaba con imágenes textuales, objetos y dibujos manuscritos. ${ }^{39} \mathrm{El}$ hecho de que muchos de los grabados impresos fueran

36 Una dinámica similar se detecta en las cosmografías universales, cuyo período de auge también se constata entre mediados y fines del siglo XVI (Martínez, 2019b).

${ }^{37}$ Esta falta de representatividad ha sido considerada un rasgo diferencial de los libros de trajes del período.

${ }^{38}$ En la opinión de esta autora, la escasa presencia de trajes de América pondría en evidencia, además, que para sus creadores "en estas poblaciones se encuentran atenuados o ausentes los criterios de diferenciación y jerarquización social" (Vega, 2014: párr.32).

39 Odile Blanc resalta, además, la influencia que tanto las performances cuanto los objetos contenidos en los gabinetes de curiosidades pudieron haber tenido en la elaboración de los 
el producto de experiencias en regiones excéntricas ${ }^{40}$ a los núcleos económicopolíticos iberoamericanos explicaría la prevalencia de figuras vinculadas a los habitantes de Brasil en una primera fase de los libros de trajes y la inclusión de grabados sobre Virginia en un segundo período. Por otra parte, es probable que la inclusión de las vestimentas del "Rey del Perú" y su mujer, constatada a lo largo de todo el período, respondiera a los procesos de traducción, reedición y circulación de las crónicas españolas referidas a los acontecimientos andinos. ${ }^{41}$ Resta indagar, sin embargo, en torno al origen específico de estas imágenes.

Del conjunto de libros de trajes mencionado al inicio de esta sección, incluyeron imágenes sobre las vestimentas de América las obras de Desprez, Jost, Bertelli (en sus ediciones de 1569 y 1596), Bruyn, Boissard y la segunda edición del texto de Vecellio. Por tratarse de la primera obra del género, merece particular atención la presencia de modelos americanos en Recueil de la diversité des habits qui sont de présent en usage tant es pays d'Europe, Asie, Afrique et isles sauvages, de François Desprez. Publicado in-octavo por Richard Breton en 1562, el compendio presentaba las vestimentas de los habitantes de "las islas salvajes" a través de tres figuras depuradas de todo fondo o paisaje. Se trataba de: "el salvaje en pompa", "la brasileña" y "el brasileño" (Figuras 5, 6 y 7, respectivamente). Al igual que las 121 imágenes que integraban la compilación, cada grabado estaba acompañado de un breve texto explicativo en la base.

libros de trajes: "Los escritos sobre América son numerosos, los objetos provenientes de América decoran los gabinetes de curiosidades, pero las imágenes son raras y solo se diversifican tardíamente." (Blanc, 2006: 84).

40 Tal como fueron los viajes de Vespucio, Staden, Thevet y Léry a Brasil, de Schmidl al Río de la Plata y, hacia fines de ese mismo siglo, de los ingleses a Florida y Virginia.

${ }^{41}$ Hacia 1556, los acontecimientos en Perú se habían dado a conocer en español por medio de: Historia del descubrimiento y conquista del Peru: con las cosas naturales que señaladamente alli se hallan, y los sucesos que ha auido (1555) de Agustín de Zárate; Verdadera relación de la conquista del Perú (1534) de Francisco de Xerez; Conquista del Peru: verdadera relacion dela conquista del Peru [et] provincia del Cuzco llamada la nueua Castilla, conquistada por Francisco picarro... (1547) de Francisco de Xerez; Coronica de las Indias: la hystoria general de las Indias agora nuevamente impressa corregida y emendada (1547) de Gonzalo Fernández de Oviedo; La historia general de las Indias y nuevo mundo con mas la conquista del Peru y de Mexico (1555) de Francisco López de Gómara; Primera y segunda parte de la historia general de las Indias con todo su descubrimiento y cosas notables que han acaecido dende que se gano la Española y el Peru: con la conquista de Mexico y de la nueva España (1553) de Francisco López de Gómara y La historia general de las Indias, con todos los descubrimientos y cosas notables que han acaecido enellas, dende se ganaron hasta agora (1554) del mismo cronista. A su vez, algunos de estos textos habían sido traducidos al italiano para integrar el tercer volumen de Navegaciones y viajes (1556) de Giovanni Battista Ramusio y pasados luego al francés. En 1545 por ejemplo, se editaría en París L'histoire de la Terre Neuue du Perù en l'Inde Occidentale, qui est la principale mine d'or du monde, nagueres descouuerte, $\mathcal{E}$ conquise, $\mathcal{E}$ nommeé la nouuelle Castille, de Gonzalo Fernández de Oviedo. Por otra parte, entre 1555 y 1576 se publicaron en Venecia al menos seis ediciones de Chrónica del Perú de Pedro Cieza de León (Horodowich, 2005: 1042). 


\section{Figuras 5, 6 y 7}

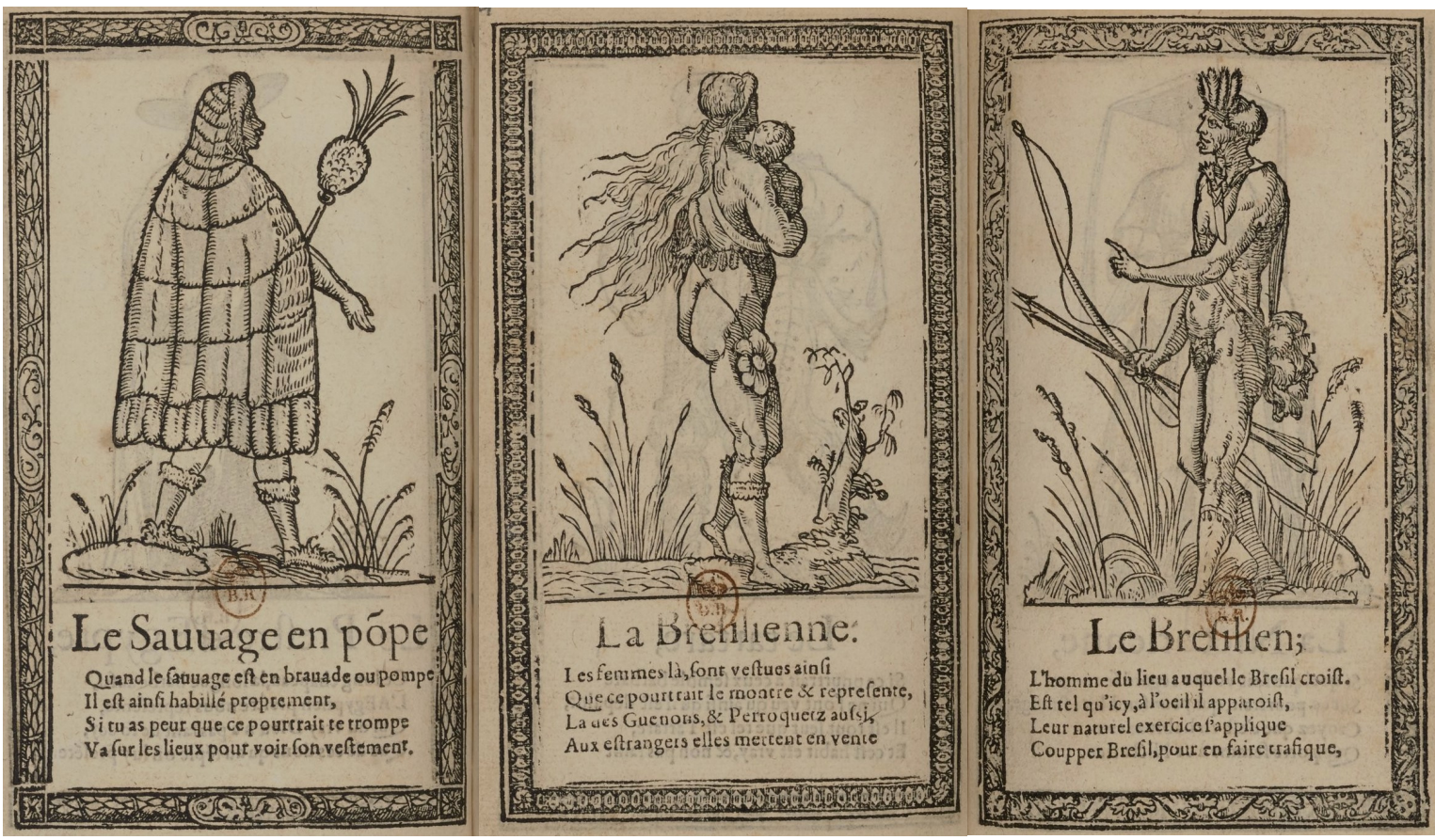

"El salvaje en pompa”, “la brasileña” y "el brasileño", en François Desprez, Recueil de la diversité des habits..., 1567 [1562], pp. 102, 104 y 105. Fuente: Biblioteca Nacional de Francia.

En la elección del tocado de plumas, el arco, las flechas, la desnudez y los accesorios de las tres figuras se constata el proceso de síntesis iconográfica ya presente en los grabados publicados junto a las escrituras fundacionales referidas a Terra Brasilis y a las poblaciones tupi-guaraníes de sus costas, específicamente. A la vez, la lectura atenta de los textos ubicados en la base de cada una de ellas confirma no solo la importancia del testigo ocular como fuente de autoridad en la modernidad temprana, sino el creciente poder de la imagen en detrimento de otras formas de conocimiento. El impacto que el hallazgo de un mundo jamás descripto por los Antiguos produjo en los criterios de verdad y métodos cognitivos hasta entonces privilegiados se observa particularmente en la descripción referida al salvaje vestido para participar de alguna celebración o rito. El texto en la base indica: “Cuando el salvaje está de guapería o en pompa, se viste exactamente así. Si tienes miedo de que este retrato te engañe, ve hasta allí para ver su vestimenta" (Figura 5).

Desprez desafía al lector a recorrer los territorios americanos en el caso de no confiar en la descripción visual que el libro propone. ${ }^{42}$ A la vez, la

\footnotetext{
${ }^{42}$ Frente a lo inusitado del Nuevo Mundo, la interpelación a ver con los propios ojos todo lo que se describía sobre América fue una constante en muchos relatos de viaje. En Histoire d'un voyage faict dans la terre $d u$ Brésil, por ejemplo, Jean de Léry invitaba a sus lectores a viajar a aquellas tierras para comprobar por sí mismos lo narrado en el texto: "más allá de que habiendo permanecido en aquella región alrededor de un año haya sido lo suficientemente curioso para contemplar a grandes y a pequeños, caí en la cuenta de que aun viéndolos frente a mis ojos, no
} 
necesidad de refrendar la imagen con un texto en el que se aclara que todo es "tal como aquí aparece" demuestra que, si el grabado hace creíble la experiencia sobre el terreno, es la palabra escrita la que aún lo inviste de autoridad. ${ }^{43}$ En cuanto al valor del testimonio, Anthony Pagden ha explicado que si bien la autopsia era una antigua categoría de la retórica, ${ }^{44}$ entre los siglos XVI y XVII el recurso se volvió un mecanismo efectivo para crear textos de autoridad sobre temas y lugares de los que nunca antes se había hablado (1993: 54). Por su parte, la importancia de la imagen como complemento de lo narrado ha sido refrendada por Lisa Voigt y Elio Brancaforte, para quienes "las ilustraciones también reforzaban las afirmaciones textuales sobre la experiencia $\mathrm{y}$ autenticidad del testigo" (2014: 366).

Paradójicamente, es notable que sea el propio Desprez quien aclare en su dedicatoria al Príncipe Enrique de Navarra que ha obtenido los modelos para ilustrar las vestimentas de los "salvajes" y "brasileños" de bocetos elaborados por un portugués cuyo nombre no menciona y del propio Jean-François de la Rocque de Roberval, quien fuera teniente general de Nueva Francia (actual Canadá) entre 1541 y $1543 .{ }^{45}$ Desprez explica:

"realicé esta colección que contiene la diversidad de vestimentas que se utilizan actualmente tanto en Europa, Asia [y] África como en las islas de los salvajes y bárbaros, siguiendo algún dibujo del difunto Roberval, capitán del Rey, y de un cierto portugués que frecuentó varios y diversos países, parecidos a los que vemos diariamente" (1567: s/p). ${ }^{46}$

tendría nunca una idea y una imagen en mi raciocinio: tal es así que a causa de sus gestos y compostura tan distintos a los nuestros, confieso que es difícil representarlos correctamente, ni por escrito ni tampoco en imágenes. Por lo cual, para tener tal satisfacción hay que verlos y visitarlos en su país" (Léry, 1578: 233-4).

${ }^{43}$ La correlación entre texto e imagen, testimonio y autoridad también puede observarse en las descripciones al pie de las otras dos figuras. Sobre la mujer brasileña Desprez afirma: "Las mujeres de allí se visten de la forma en que este retrato las muestra y representa". En el caso del hombre brasileño, indica: "El hombre del lugar en el cual crece el brasil es tal como aquí aparece ante el ojo". A la vez, Desprez completa el cuadro con información sobre sus actividades: mientras la mujer se dedica al comercio de aves, el hombre corta y vende palo-brasil, cuyos taninos eran utilizados en la producción pañera de la ciudad de Ruan.

${ }^{44}$ Tal como la define Pagden, la autopsia consistía en "la apelación a la autoridad del testigo ocular, al entendimiento privilegiado que aquellos presentes en un acontecimiento podían tener sobre aquellos que sólo habían leído u oído sobre el mismo" (Pagden, 1993: 51).

${ }^{45}$ Tras el fracaso de la empresa colonizadora en Canadá, Roberval también se dedicó al pillaje en el Mar Caribe.

${ }^{46}$ [" J'ai fait ce recueil contenant la diversité des habits qui sont à present en usage, tant en Europe, Asie, Afrique, que aux Isles des Sauvages et barbares, ayant suivy quelque dessein du defunct Roberval, Capitaine pour le Roy, et d'un certain Portugais ayant frequenté plusieurs et divers pays, semblablement de ceux que nous voyons journellement a l'œil..."] 
En cuanto a la alusión a Roberval, no resulta del todo claro cuáles fueron sus posibles contribuciones, pues la obra de Desprez no presenta grabados en los que se muestren las vestimentas de Nueva Francia, territorio que el teniente conocía por su propia experiencia al servicio de la corona. Al margen de esto último, interesa a los fines del presente trabajo que, más allá de incitar al lector a observar las vestimentas con sus propios ojos, el propio Desprez no fue más que un intermediario o intérprete de las ilustraciones producidas a partir de experiencias ajenas en el Nuevo Mundo.

Los modelos americanos presentados por Desprez volvieron a hacerse presentes en Habitus praecipuorum populorum, obra de Jost Amman publicada por Hans Weigel en Núremberg hacia $1577 .{ }^{47}$ De hecho, las únicas tres figuras representativas de América incluidas por Amman en la edición referida son reversiones del "salvaje en pompa" y del hombre y mujer brasileños presentados por Desprez en 1562. En el caso de Amman, sin embargo, las figuras han ganado precisión pues sus trajes y accesorios están representados con aún más detalle que en la obra del francés. Esto se ve particularmente en el caso del brasileño "vestido para la guerra" (Figura 8), que sostiene en su mano izquierda el Iwera Pemme. ${ }^{48}$ Ha sido señalado ya cómo las ediciones del viaje de Staden realizadas por Kolbe y Plantin describieron su uso y apariencia, que el propio Ortelius retomó al componer la alegoría de Pars Quarta en su Theatrum Orbis Terrarum (Waterschoot, 1979: 53). Ahora bien, si los grabados se habían vuelto más detallados, su identificación con una determinada geografía de América aún resultaba confusa. El hombre y mujer presentados en la Figura 9, por ejemplo, son descriptos como habitantes de las "nuevas islas" del Brasil vestidos con "trajes del Perú". En la obra de Amman, la necesidad de dar cuenta de las cuatro partes del mundo pareciera haberse impuesto a la precisión geográfica requerida para ello.

\footnotetext{
${ }^{47}$ Su título completo fue: Habitus praecipuorum populorum, tam virorum quam foeminarum Singulari arte depicti. Trachtenbuch: Darin fast allerley und der fürnembsten Nationen/die heutigs tags bekandt sein/Kleidungen beyde wie es bey Manns und Weibspersonen gebreuchlich/mit allem viess abgerissen sein/sehr lustig und kurtzweilig zusehen.

${ }^{48}$ Se trataba de un instrumento ceremonial ornamentado con el que los prisioneros de guerra eran golpeados a muerte antes de ser devorados por los tupíes.
} 


\section{Figura 8}

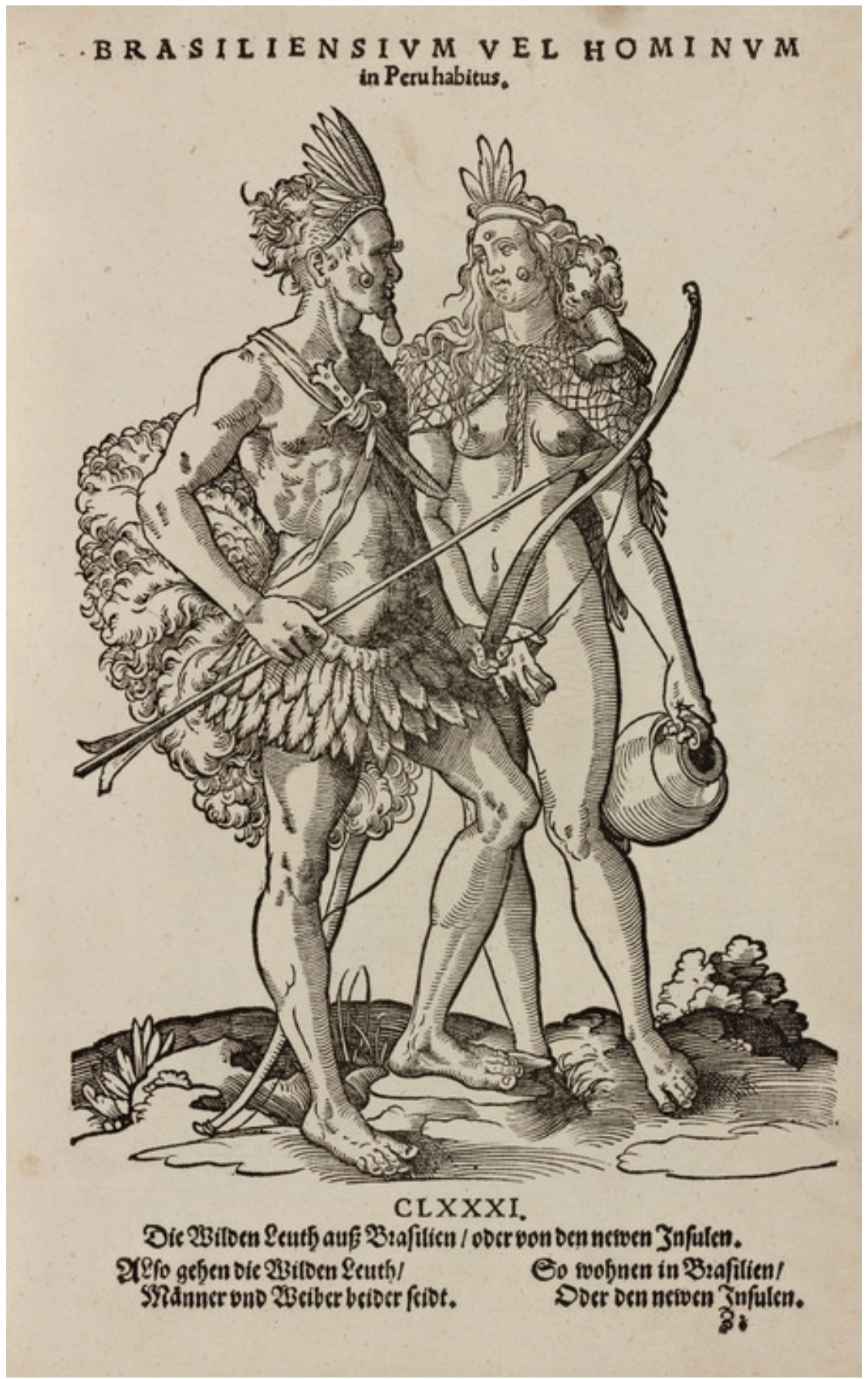

"Brasiliensium vel Hominum in Peru habitus" (Plancha 181). Amman, Jost, Habitus praecipuorum populorum, Núremberg, Hans Weigel, 1577. Fuente: Spencer Collection, The New York Public Library. The New York Public Library Digital Collections. ${ }^{49}$

${ }^{49}$ Imagen disponible en: http://digitalcollections.nypl.org/items/acd02be0-a0ed-0132-ad5b58d385a7b928 


\section{Figura 9}

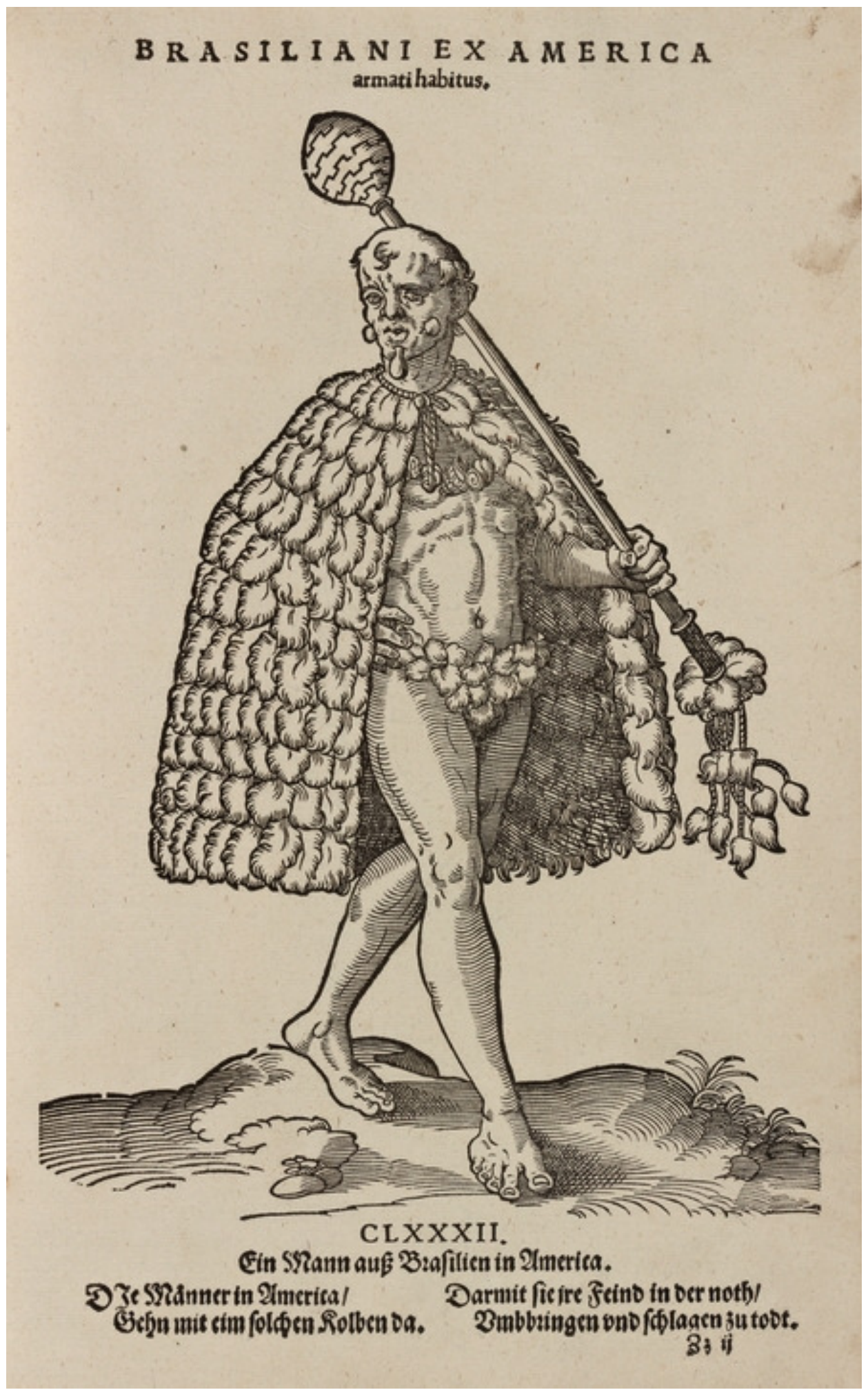

"Brasiliani ex America armati habitus" (Plancha 182). Amman, Jost, Habitus praecipuorum populorum, Núremberg, Hans Weigel, 1577. Spencer Collection, The New York Public Library. The New York Public Library Digital Collections. ${ }^{50}$

${ }^{50}$ Imagen disponible en: http://digitalcollections.nypl.org/items/a19445b0-a0ed-0132-412d58d385a7b928 
La pervivencia del hombre y mujer brasileños como arquetipos de los trajes de América vuelve a constatarse en Omnium pene Europae, Asiae, Aphricae atque Americae Gentium Habitus, publicado por Abraham Bruyn en Amberes en 1581. Hacia el final del libro, Bruyn incluye una plancha en la que se ilustran los trajes de América, las Indias Orientales y África a través de seis parejas. En la fila superior a la izquierda se observan los trajes de un hombre y mujer americanos, iguales en sus poses, vestidos y accesorios a las imágenes presentadas por Desprez y Amman en 1562 y 1577 respectivamente. Resulta novedosa, en cambio, la inclusión de una "mujer noble de América" y de "Athabalippa (Atahualpa), último rey de América" en la fila inferior a la izquierda (Figura 10). Este par volverá a aparecer en el Recueil de costumes étrangers de Jean-Jacques Boissard, publicado algún tiempo después de 1581 (Figura 11$)^{51}$ y en la edición de Diversarum nationum habitus realizada por Pietro Bertelli en Padua hacia 1589.52

\section{Figura 10}

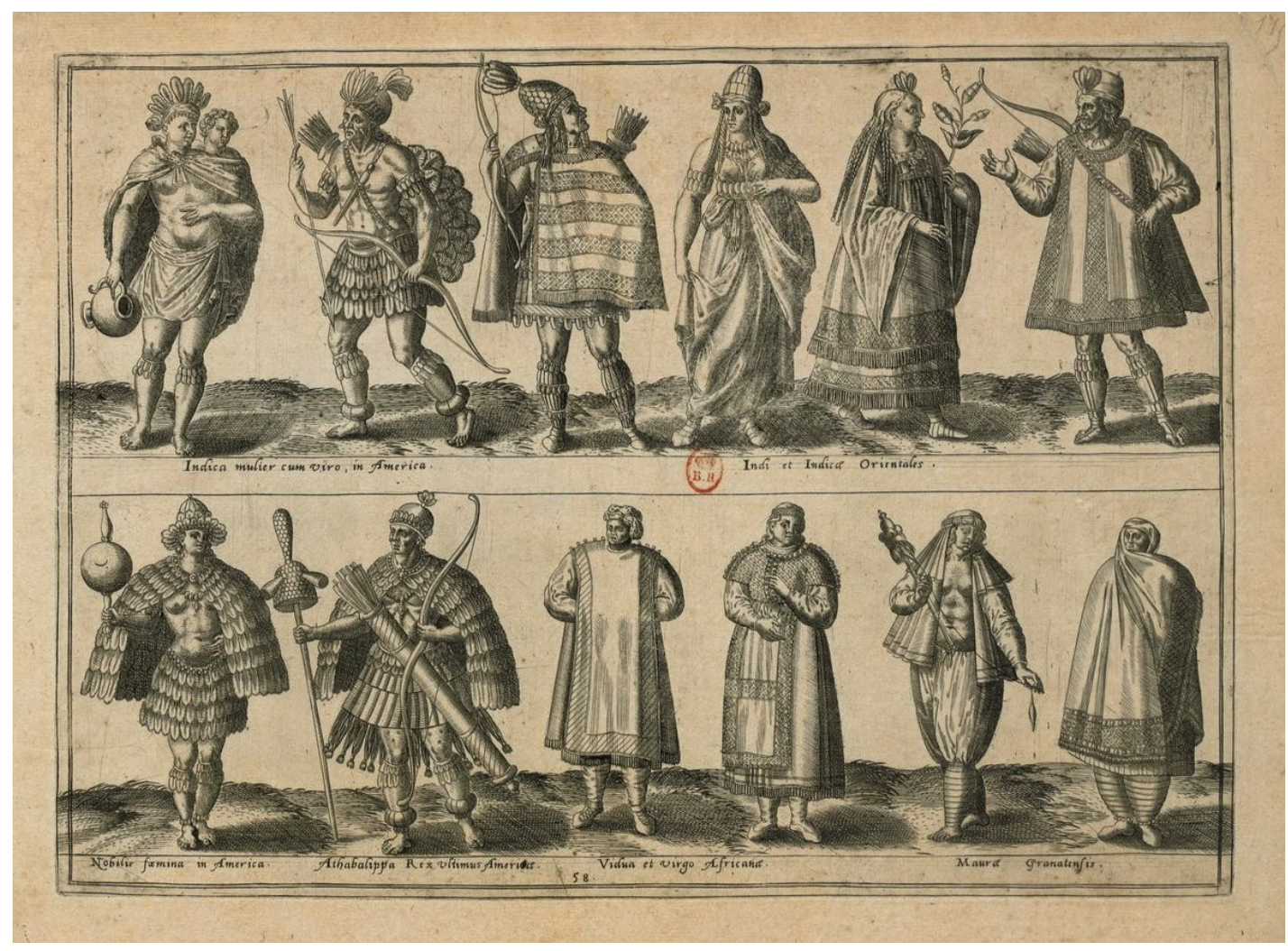

Bruyn, Abraham, Omnium pene Europae, Asiae, Aphricae atque Americae Gentium Habitus, Amberes, 1581.53 (Folio 58) Fuente: Biblioteca Nacional de Francia.

\footnotetext{
${ }^{51}$ En la obra de Boissard, sin embargo, la "mujer noble" de Bruyn llevará por título "Mujer del rey de América".

${ }^{52}$ La pareja inca introducida por Bertelio sería copiada e incluida por Alessandro Fabri en su Diversarum nationum ornatus cum suis iconibus, publicado en Padua en 1593 (Horodowich, 2005: 1055).

${ }^{53}$ Imagen disponible en:

https://gallica.bnf.fr/ark:/12148/btv1b55001874r/f229.item.r=bruyn\%20omnium\%20pene
} 
Tanto la composición de Bruyn como la de Boissard evidencian la estandarización o tipificación al que fueron sometidas las imágenes de Pars Quarta. En ambos casos, las vestimentas de lugares remotos parecen haberse concentrado en una única plancha donde, ${ }^{54}$ a excepción de cada traje, no hay diferencias visibles en el tamaño y rasgos de los hombres y mujeres que la componen.

\section{Figura 11}

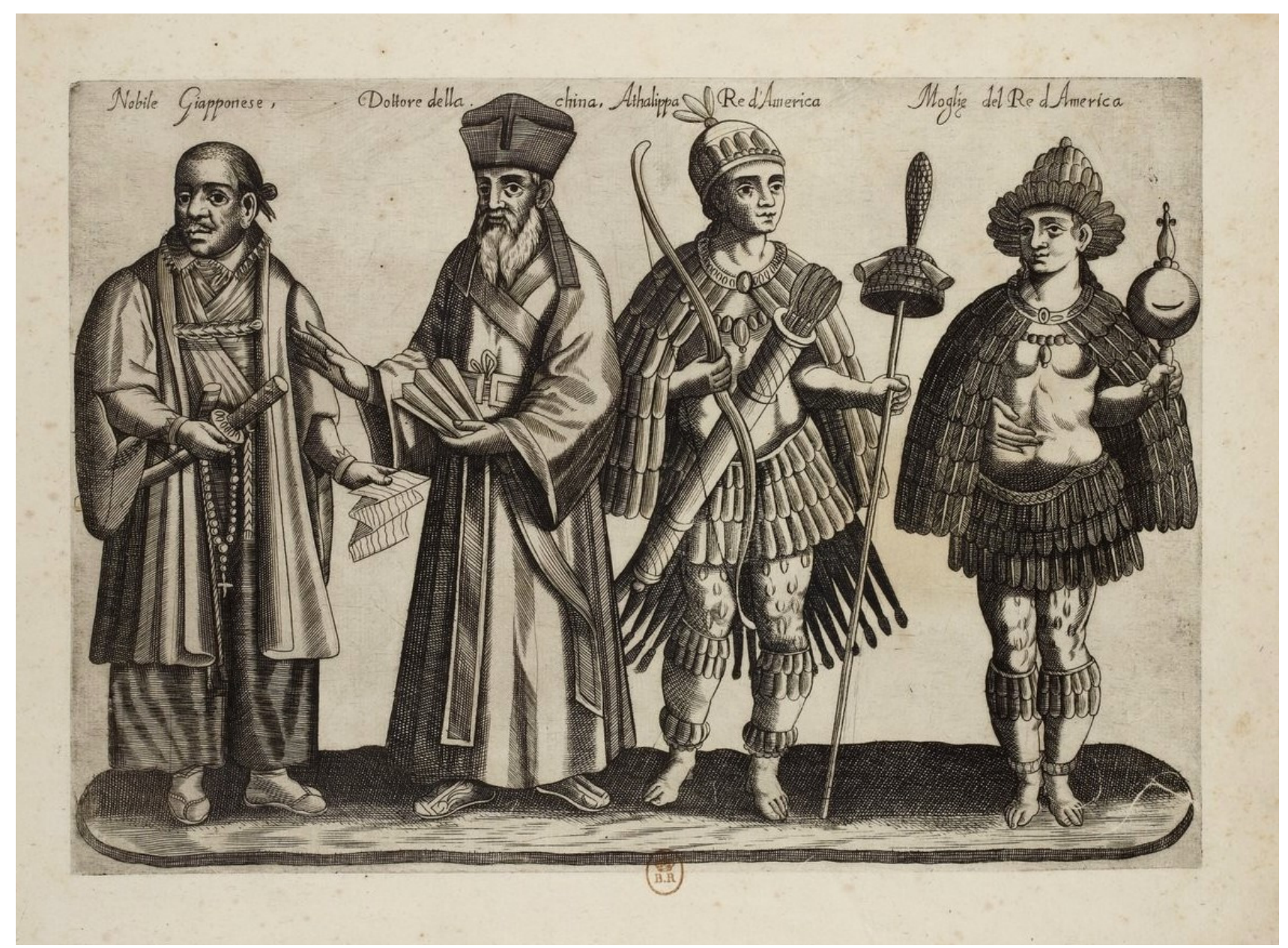

Boissard, Jean-Jacques. Recueil de costumes étrangers..., [S. 1.], Jean-Jacques Boissard, post. $1581 .{ }^{55}$ (Folio 56) Fuente: Biblioteca Nacional de Francia.

A diferencia de las obras hasta aquí examinadas, donde la influencia de los relatos fundacionales sobre los libros de trajes no puede rastrearse a un único texto, en la segunda edición de De gli Habiti antichi et moderni di Diverse

\footnotetext{
${ }^{54}$ De hecho, en el caso de Boissard la mujer de Athabalippa y el propio rey se encuentran ubicados junto a un "noble japonés" y a un "doctor chino" en una única plancha.

${ }^{55}$ Imagen disponible en: https://gallica.bnf.fr/ark:/12148/btv1b84471317/f61.item
} 
Parti del Mondo, realizada por Cesare Vecellio en 1598, el origen de las figuras correspondientes a Virginia puede ubicarse con claridad. En principio, el rasgo más sobresaliente de aquella segunda edición fue la inclusión del Volumen XII, que presentaba veinte láminas dedicadas a "De gli habiti dell'America" ("Los trajes de América"). Vecellio fue el primero en presentar de forma ordenada y sistemática las vestimentas de los habitantes de Perú, México, Virginia y Florida, que junto a los trajes de otras naciones permitían dar cuenta de aquella ecúmene ampliada por la expansión transoceánica.

En lo que refiere al tratamiento de imágenes sobre el Nuevo Mundo, esto hace de su obra la más completa del género. En lo particular, respecto de los trajes asociados a Virginia, la influencia de Teodoro de Bry es evidente. Al igual que Pietro Bertelli en la edición de Diversarum nationum habitus de 1596,56 Vecellio recurrió a los grabados que acompañaron la edición del Briefe and True Report of the New Found Land of Virginia de Thomas Harriot realizada por Teodoro de Bry en 1590 (Figuras 12 y 13). ${ }^{57}$ Las planchas, realizadas por el grabador de Frankfurt en base a las acuarelas hechas por el dibujante John White durante su estancia en la isla de Roanoke (1585), fueron reproducidas por el veneciano con muy pocas alteraciones. Su reutilización en un nuevo contexto no debe ser considerada, sin embargo, un mero acto de copia. Aun si se tratara de versiones casi idénticas a los grabados de De Bry, depuradas de su referencialidad original, en la obra de Vecellio las imágenes de Virginia integraron nuevas cadenas de sentido. En este sentido, el caso De Bry-Vecellio hecha luz sobre los circuitos recorridos por las imágenes sobre el Nuevo Mundo pero también sobre las apropiaciones y sentidos cambiantes del repertorio iconográfico americano.

\footnotetext{
${ }^{56}$ En su obra, Bertellio había incluido una "Mulier Virginiae Insulae Habitatrix", cuyo modelo estaba claramente inspirado en las imágenes que habían acompañado el texto de Harriot.

${ }^{57}$ Para un análisis detallado de la participación de Harriot en el asentamiento inglés de Virgina y la posterior edición de su informe véase: López Palmero (2013).
} 
Figuras 12 y 13
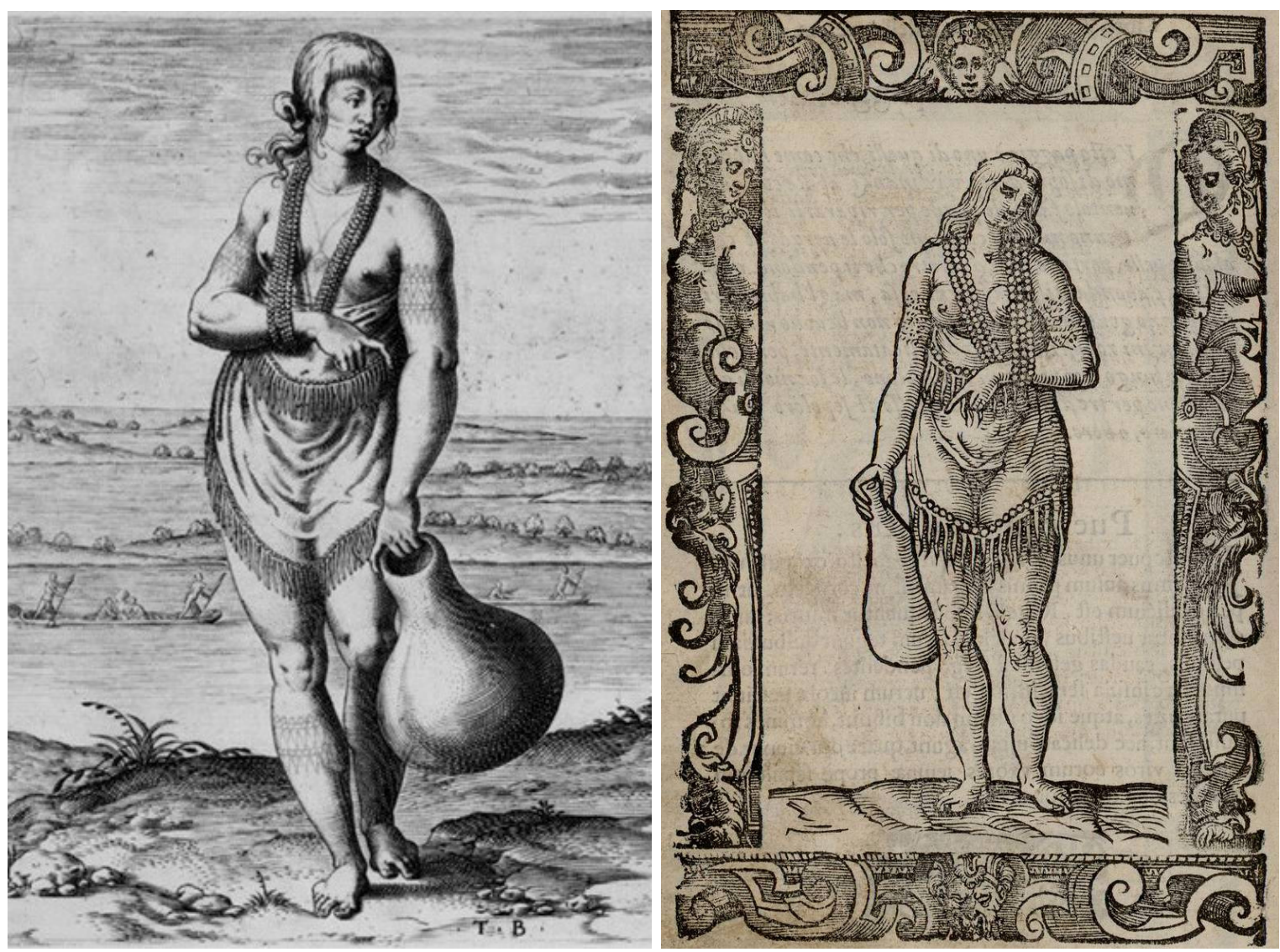

A la izquierda, detalle de "A cheiff Ladye of Pomeiooc", en De Bry, Theodore, Americae, pt.1, 1590, pl. VIII. A la derecha, "Habito delle matronee, donzelle". Vecellio, Cesare, De gli Habiti antichi et moderni di Diverse Parti del Mondo, Venecia, Gio. Bernardo Sessa, 1598, p. 500v. Fuente: Biblioteca Virtual del Patrimonio Bibliográfico, España.

\section{Consideraciones finales}

A lo largo del presente artículo han sido examinadas dos fases diferenciadas en la consolidación de un imaginario sobre el Nuevo Mundo. La primera, referida a la producción de las imágenes que acompañaron a las "escrituras fundacionales" de América. La segunda, relativa a la inclusión tipificada de dichas figuras en repertorios iconográficos más amplios, tal como fueron los libros de trajes. Lejos de tratarse de dos etapas secuenciadas temporalmente, las instancias referidas remiten a operaciones intelectuales específicas vinculadas a la puesta en disposición de un saber general y espacialmente ordenado del mundo conocido. 
La inclusión de imágenes relativas a América en géneros no necesariamente dedicados al Nuevo Mundo ha sido interpretada como el reflejo de un proceso de conformación y síntesis de "lo americano", evidenciado en la creación de la alegoría de América y su definición como Pars Quarta, entre otras manifestaciones visuales y teóricas de mediados y fines del siglo XVI. En este contexto, la presencia de la "mujer brasileña" o del "rey Athabalippa" en los libros de trajes analizados parece haber obedecido a una lógica de "incorporación y distanciamiento" que, al incluir, normalizar y sintetizar las imágenes americanas dentro de géneros más amplios, las alejó también de sus contextos originales de producción.

Si a primera vista el auge del género obedeció al crecimiento de un mercado editorial ávido por producir y consumir este tipo de impreso, ${ }^{58} \mathrm{su}$ consolidación respondió a su capacidad de dar cuenta de una ecúmene ampliada por los viajes de exploración. La intención de ordenar y exhibir el conocimiento del mundo en nuevos dispositivos textuales convirtió a los libros de trajes en depositarios de un saber global, incompleto y asimétrico pero lo suficientemente flexible como para incorporar nuevas informaciones. En términos de Giorgio Riello, el libro de trajes suscribió a una noción de 'lo global' que fue "modular, maleable y expandible" en la medida en que permitió “imaginar geografías globales y articularlas" (2019: 316). A su vez, los libros de trajes operaron como complemento de otros géneros disponibles pues, al igual que los mapas, "funcionaron como obras de referencia visual que reunían y elaboraban información etnográfica a partir de los relatos de viaje" (Davies, 2016: 264).

Por todo lo dicho, el análisis de los libros de trajes invita a reflexionar sobre el período de balance, síntesis y reformulación del saber experimentado en la Europa de mediados del siglo XVI. ${ }^{59}$ En relación con estos procesos, debe señalarse por último que la consolidación de una imagen distintiva de América también respondió a los intereses políticos presentes tanto en el ámbito de su producción como de su circulación a través de los agentes involucrados en ellos.

Buenos Aires, marzo de 2020.

\footnotetext{
${ }^{58}$ Para Odile Blanc, "el desarrollo del libro de trajes debe comprenderse en estrecha correlación con el papel esencial de los impresores así como con la intensa circulación de imágenes ligadas al auge del impreso" (2006: 78). Otras explicaciones han girado en torno a sus fines propagandísticos en el marco del conflicto religioso entre católicos y protestantes. George Thomas (2014), por ejemplo, ha vinculado la popularidad del género al contexto de guerra entre la monarquía española y las futuras Provincias Unidas de los Países Bajos.

${ }^{59}$ Este tiempo de balance y síntesis ha sido especialmente trabajado para el caso de la geografía por Jean-Marc Besse (2005: 95).
} 


\section{Bibliografía citada}

Amman, Jost (1577). Habitus praecipuorum populorum, tam virorum quam foeminarum Singulari arte depicti. Trachtenbuch: Darin fast allerley und der fürnembsten Nationen/die heutigs tags bekandt sein/Kleidungen beyde wie es bey Manns und Weibspersonen gebreuchlich/mit allem viess abgerissen sein/sehr lustig und kurtzweilig zusehen, Núremberg: Hans Weigel.

Amman, Jost (1586). Gynaeceum, sive theatrum mulierum, Frankfurt: Sigmund Feyerabendt.

María Jesús Benites (2014). "Vigilias, fatigas y peregrinaciones": viaje, relato y desamparo en los confines del imperio", en Telar, núm. 11-12, pp. 80-97.

Bertelli, Pietro (1589). Diversarum nationum habitus centum et quattuor iconibus in aere incisis diligenter expressi, item ordines duo processionum, unus Summi Pontificis, alter Sereniss. Principis Venetiarum, opera Petri Bertellii..., Padua: s/e.

Besse, Jean-Marc (2005). "El nacimiento del atlas moderno: Ortelius, Lafreri”, en Jaurata, Francisco (ed.) El mundo de los mapas, Santander: Universidad Nacional Menéndez Pelayo.

Blanc, Odile (2006). "Ethnologie et merveille dans quelques livres de costumes français", en Viallon, Marie (ed.) Paraitre et se vêtir au XVIe siècle. Actes du XIIIe Colloque du Puy-en-Velay, Saint-Étienne: Publications de l'Université de SaintÉtienne, 2006, pp. 79-94.

Boissard, Jean-Jacques (post. 1581). Recueil de costumes étrangers...], s/1 : JeanJacques Boissard.

Broc, Numa (1986). La géographie de la Renaissance, París: CTHS.

Bruyn, Abraham (1581). Omnium pene Europae, Asiae, Aphricae atque Americae Gentium Habitus, Amberes: s/e.

Bruyn, Abraham y Boissard, Jean-Jacques (1581 [1570]). Habitus variarum Orbis Gentium. Habitz de nations estranges, Amberes: s/e.

Carvalho, Larissa (2019). "Contact, Perception and Representation of the 'American Other' in Sixteenth-Century Costume Books", en Graziani, Irene y Spissu, Maria Vittoria (Eds.), Il mito del nemico. Identità, alterità e loro rappresentationzioni, Argelato: Minerva, pp. 235-244.

Carvalho, Larissa (2020). “Vico a Vecellio: indagações sobre a circulação de modelos nos livros de trajes do século XVI", en Figura. Studies on the Classical Tradition, vol. 8, núm. 1, pp. 184-210.

Chicangana-Bayona, Yobenj Aucardo (2013). Imágenes de caníbales y salvajes del Nuevo Mundo. De lo maravilloso medieval a lo exótico colonial. Siglos XVXVII, Bogotá: Universidad del Rosario. 
Davies, Surekha (2016). Renaissance Ethnography and the Invention of the Human: New Worlds, Maps, Maps and Monsters, Cambridge: Cambridge University Press.

De Bry, Theodore (1590). Americae, Primera Parte, Frankfurt: De Bry.

Defert, Daniel (1984). “Un genre ethnographique profane au XVIe: les libres d'habits (essai d'ethno-iconographie)", en Rupp-Eisenreich, Britta (ed.), Histoires de l'anthropologie (XVIe-XIXe siècles), París: Klincksieck, pp. 25-41.

Desprez, François (1562). Recueil de la diversité des habits qui sont de présent en usage tant es pays d'Europe, Asie, Afrique et isles sauvages, París: Richard Breton.

Duviols, Jean-Paul (1985). L'Amérique espagnole vue et revée selon les récits de voyage de Christophe Colomb à L. A. de Bougainville 1492-1768, París: Promodis.

El Jaber, Loreley (2013). “Lectores, autores y editores en los siglos XVI y XVII. El 'fenómeno' Ulrico Schmidl”, en Zama, núm. 5, pp. 135-143. Recuperado de: https://doi.org/10.34096/zama.a5.n5.1147

Ehrlicher, Hanno (2014). "Funciones de la antropofagia en la Verdadera historia de Hans Staden y en El entenado de Juan José Saer", en Orbis Tertius, vol. XIV, núm. 20, pp. 85-94. Recuperado de:

https://www.orbistertius.unlp.edu.ar/article/view/OTv19n20a10

Horodowich, Liz (2005). "Armchair Travelers and the Venetian Discovery of the New World", en The Sixteenth Century Journal, vol. 36, núm. 4, pp. 1039-1062.

Ilg, Ulrike (2004). “The cultural significance of costume books in SixteenthCentury Europe", en Richardson, C. (ed.), Clothing culture, 1350 - 1650 (pp. 2947), Aldershot: Ashgate.

Jones, Ann Rosalind (2006). "Habits, Holdings, Heterologies: Populations in a 1562 Costume Book", Yale French Studies, núm. 110: Meaning and Its Objects: Material Culture in Medieval and Renaissance France, pp. 92-121.

Joris de Zavala, Hugette (1983). “L'allégorie de l'Amérique dans l'art européen", en Jahrbuch für Geschichte Lateinamerikas/Anuario de Historia de América Latina (JbLA), núm. 20, pp. 563-574.

Kwiatkowski, Nicolás (2017). "Palabra e imagen en la modernidad temprana. Representaciones de la barbarie mediante ilustración, écfrasis y alegoría”, en Boletín de Estética, núm. 39, año XIII, pp. 43-94.

Léry, Jean de (1578). Histoire d'un voyage faict en la Terre du Brésil, autrement dite Amérique, La Rochelle: Antoine Chuppin.

Lestringant, Frank (1991). "Le déclin d'un savoir. La crise de la cosmographie à la fin de la Renaissance", Annales. Économies, Sociétés, Civilisations, año 46, núm. 2, pp. 239-260.

Lois, Carla (2008). “América quarta pars: ¿isla o continente? El debate conceptual sobre el estatus geográfico del Nuevo Mundo en el siglo XVI", en Fronteras de la 
Historia, vol. 13, núm. 2, 2008, pp. 159-279. Disponible en: http://www.redalyc.org/pdf/833/83313202.pdf

López Palmero, Malena (2013). “Capítulo 3: Thomas Hariot: viajero y científico de la Inglaterra isabelina", en Gandini, María Juliana, López Palmero, Malena, Martínez, Carolina y Paredes, Rogelio C., Fragmentos Imperiales. Textos e imágenes de los imperios coloniales en América, Siglos XVI-XVIII, Buenos Aires: Editorial Biblos, pp. 69-101.

Martínez, Carolina (2019a). “'Salvajes desnudos, feroces y caníbales': textos fundacionales e imágenes cartográficas en la construcción de América como Pars Quarta", en Tieffemberg, Silvia (comp.) Pensar América desde sus colonias. Textos e imágenes de América colonial, Buenos Aires: Biblos, pp. 37-58.

Martínez, Carolina (2019b). "Antiguos y modernos en la construcción de una nueva imagen del mundo. El auge del género cosmográfico en el siglo XVI", en Eadem Utraque Europa, núm. 20, pp. 63-93.

Mentges, Gabriele (2007). “Pour une approche renouvelée des recueils de costumes de la Renaissance. Une cartographie vestimentaire de l'espace et du temps", en Apparence(s). Histoire et culture du paraître, núm. 1, s/p. Disponible en: http://apparences.revues.org/104

Moseley-Christian, Michelle (2013). "Confluence of Costume, Cartography and Early Modern European Chorography", en Journal of Art Historiography, núm. 9, $\mathrm{s} / \mathrm{p}$.

Olian, Jo Anne (2013). "Sixteenth-Century Costume Books", Dress, núm. 3, vol. 1 , pp. 20-47.

Ortelius, Abraham (1570). Theatrum Orbis Terrarum, Amberes: s/e.

Pagden, Anthony (1993). European Encounters with the New World. From Renaissance to Romanticism, New Haven \& London: Yale University Press.

Pellegrin, Nicole (1987), "Vêtements de peau(x) et de plumes: la nudité des indiens et la diversité du monde au XVIIe siècle", en Céard, Jean y Margolin, Jean-Claude (eds.), Voyager à La Renaissance. Actes du colloque de Tours 30 juin-13 juillet 1983, París: Maisonneuve et Larose, pp. 509-529.

Riello, Giorgio (2019). "The World in a Book: The Creation of the Global in Sixteenth-Century European Costume Books", Past E Present, vol. 242, núm. 14, pp. 281-317. Disponible en: https://doi.org/10.1093/pastj/gtz047

Ripa, Cesare (1603). Iconologia, overo, descrittione di diverse imagini cavate dall'antichita, $\mathcal{E}$ di propria inventione, Roma: Appresso Lepido Facij.

Rubiés, Joan Pau (2008). “Imagen mental e imagen artística en la representación de los pueblos no europeos. Salvajes y civilizados, 1500-1650", en Palos, Joan Lluís y Carrió-Invernizzi, Diana (eds.) La historia imaginada. Construcciones 
visuales del pasado en la Edad Moderna, España: Centro de Estudios Europa Hispánica, pp. 327-358.

Schmidl, Ulrico (2016 [1567]). Derrotero y viaje a España y las Indias, Paraná: Editorial de la Universidad Nacional de Entre Ríos.

Staden, Hans (1557). Warhaftige Historia, Marburg: Kolbe.

Staden, Hans, Duas viagens ao Brasil, Introdução de Eduardo Buenos, Porto Alegre, L\&PM, 2019.

Subrahmanyam, Sanjay (2005), "On World Historians in the Sixteenth Century", en Representations, vol. 91, núm. 1, pp. 26-57.

Thomas, George Anthony (2014) "Fashion and Nationalism: Political Critique in Early Modern Costume Books", en Laberinto Journal, núm. 7, pp. 8-26.

Van Groesen, Michiel (2012). The Representations of the Overseas World in the De Bry Collection of Voyages (1590-1634), Leiden: Brill.

Vecellio, Cesare (1598). De gli Habiti antichi et moderni di Diverse Parti del Mondo, Venecia: Gio. Bernardo Sessa.

Vega, Alejandra (2014). “Trajes del teatro del mundo: vestimenta, sujetos y diferencia americana en la primera modernidad", en Nuevo Mundo Mundos Nuevos [En línea], Debates, Puesto en línea el 03 junio 2014. Disponible en: http://journals.openedition.org/nuevomundo/66794

Vespucio, Américo (1505). Mundus Novus, Núremberg: s/e.

Voigt, Lisa y Brancaforte, Elio (2014). “The Traveling Illustrations of Sixteenth Century Travel Narratives", en PMLA, vol. 129, núm. 3, pp. 365-398.

Waterschoot, Werner (1979). “The title-page of Ortelius's Theatrum orbis terrarum: A comment", en Quaerendo, núm. 9, pp. 43-68. 